Journal of Clinical Investigation

Vol. 42, No. 11, 1963

\title{
ANTIBODY-SUPPRESSIBLE AND NONSUPPRESSIBLE INSULIN-LIKE ACTIVITIES IN HUMAN SERUM AND THEIR PHYSIOLOGIC SIGNIFICANCE. AN INSULIN ASSAY WITH ADIPOSE TISSUE OF IN- CREASED PRECISION AND SPECIFICITY*
}

\author{
By E. R. FROESCH, H. BÜRGI, E. B. RAMSEIER, P. BALLY, and A. LABHART
}

(From the Metabolic Unit of the Department of Internal Medicine, University of

Zürich, Switzerland)

(Submitted for publication January 21, 1963; accepted August 1, 1963)

Adipose tissue has been shown to respond to insulin in vitro by several groups of investigators whose work has recently been reviewed by Jeanrenaud (1). Martin, Renold, and Dagenais (2) pointed out the extreme sensitivity of adipose tissue to insulin. Renold, Sheps, and co-workers $(3,4)$ used as a metabolic index of serum insulin-like activity (ILA) the oxidation of glucose-1$\mathrm{C}^{14}$ to $\mathrm{C}^{14} \mathrm{O}_{2}$. Several investigators adopted their method with equally good results (5-7). Humbel $(8)$ and others $(9,10)$ measured the glucose uptake of epididymal adipose tissue as an index of ILA, and Ball and Merrill (11) determined the net gas exchange. When the fat-pad assay is applied to the determination of ILA in human serum, several discrepancies become apparent between its results and those obtained by other biological and immunological assay technics currently in use.

The mean value of ILA in undiluted serum of fasting normal subjects approximates $50 \mu \mathrm{U}$ per $\mathrm{ml}$ by the diaphragm technic (12-14) and about $20 \mu \mathrm{U}$ per $\mathrm{ml}$ by the immunological assay procedure of Yalow and Berson (15). The figures obtained with the adipose tissue method are substantially higher, and vary between 30 and $1,000 \mu \mathrm{U}$ per $\mathrm{ml}(4,16,17)$. Randle (18) and Willebrands, Van der Geld, and Groen (19) determined ILA in diluted serum with the diaphragm and found values in the same high range as those obtained with adipose tissue. Although these discrepancies cannot be fully explained at present, the following points are relevant. 1) Adrenaline, noradrenaline, ACTH, growth hormone, and glucagon enhance the glucose uptake of adipose tissue in vitro. In contrast to insulin, however, these lipolytic hormones do not increase

* This work was supported by grant A163 from the Schweizerische Nationalfonds. and may even depress fatty acid synthesis from glucose and promote fatty acid release from this tissue (20-23). These hormones have no effect on the diaphragm (24), with the exception of adrenaline and noradrenaline, which depress its glucose uptake $(25,26) .2)$ Several factors in human serum antagonize the effects of insulin on the diaphragm in vitro, as reviewed recently by Berson and Yalow (27). There are no antagonists in human serum other than insulin antibodies that affect the response of adipose tissue to insulin. The facts listed under 1) and 2) would tend to yield either erroneously high levels of ILA with the adipose tissue technic, or erroneously low levels with the diaphragm technic. 3) Furthermore, ILA of human serum is almost totally suppressed by insulin antibodies when measured with the diaphragm (28), but only partially so in the adipose tissue assay (29). Thus, adipose tissue might be sensitive to insulin-like substances differing from insulin in their metabolic effects on other tissues and possibly also in their immunological properties.

The following studies have been undertaken in an attempt to answer some of these questions. Besides glucose uptake, the net gas exchange of adipose tissue was used as an additional metabolic index of ILA. Net gas exchange of adipose tissue is proportional to fatty acid synthesis from glucose (30), and so is very sensitive to insulin stimulation; it entails only a relatively simple manometric measurement. The simultaneous measurement of these indexes of adipose tissue metabolism was expected to permit a distinction between truly insulin-like effects and the effects of lipolytic hormones in serum. The results demonstrate that the effects of serum on these indexes of adipose tissue metabolism cannot be distinguished from those of pure crystalline insulin. 
The major part of serum ILA, however, was not suppressed by insulin antibodies, and only a small portion that increased after glucose administration and was elevated in patients with active $\beta$-islet-cell adenoma was inhibited by antibodies. The values of suppressible ILA in normal subjects before and after glucose administration and in patients with $\beta$-islet-cell adenoma were in the same order of magnitude as those found by Yalow and Berson (15) by immunoassay. Some of the results have been presented elsewhere in preliminary form (31).

\section{METHODS}

Recrystallized pork insulin ${ }^{1}$ with an activity of 23.9 $\mathrm{U}$ per $\mathrm{mg}$ was used as a standard. A portion of 1.25 $\mathrm{mg}$ was weighed on a Mettler ultramicrobalance, dissolved in $3 \mathrm{ml} 1 / 250 \mathrm{~N} \mathrm{HCl}$, and stored at $4^{\circ} \mathrm{C}$ for no longer than 4 weeks. For each assay, serial dilutions with Krebs-Ringer bicarbonate buffer containing 200 $\mathrm{mg}$ gelatin per $100 \mathrm{ml}$ were freshly prepared. The final dilutions, containing 10 and $1,000 \mu \mathrm{U}$ per $\mathrm{ml}$, were made in Krebs-Ringer bicarbonate buffer containing $1.5 \mathrm{~g}$ albumin ${ }^{2}$ per $100 \mathrm{ml}$. Before use, the albumin was dialyzed for 24 hours against two charges of Krebs-Ringer bicarbonate buffer, and the albumin concentration was determined. The concentration of FFA in albumin buffer $(1.5 \mathrm{~g}$ per $100 \mathrm{ml}$ ) was $0.30 \mu \mathrm{Eq}$ per $\mathrm{ml}$.

Serum was separated from the red cells within 1 hour after the blood was drawn, and it was stored at $-20^{\circ} \mathrm{C}$. Shortly before use, the serum was thawed, diluted 1:5 with Krebs-Ringer bicarbonate buffer, and the glucose content was adjusted to $200 \mathrm{mg}$ per $100 \mathrm{ml}$. The flask constants of the Warburg vessels were determined according to Umbreit, Burris, and Stauffer (32). The manometers contained Brodie's solution. The net gas exchange was expressed in microliters of gas evolved or removed per gram of wet tissue per hour. No correction of the volume occupied by the tissue (between 150 and $450 \mathrm{mg}$ per flask) was applied, since the amount of tissue was relatively constant within each assay and the quantity was small compared to the total volume of the flasks (average, $15.5 \mathrm{ml}$ ).

True glucose was determined enzymaticaliy with glucose oxidase by the test combination set of Boehringer. The samples were pipetted into the reagent mixture on ice, and then transferred to a water bath at $37^{\circ} \mathrm{C}$, where the color reaction proceeded during 20 minutes in the dark. Best precision was obtained when the same sample micropipette ${ }^{3}$ was used for the consecutive pipetting of

\footnotetext{
${ }^{1} \mathrm{We}$ are indebted to Dr. J. Schlichtkrull, Novo Terapeutisk Laboratorium A/S, Copenhagen, Denmark, for the supply of this material and crystalline human insulin.

2 Human albumin, fraction 5, purified, lot no. 6001, of the Blutspendedienst, Schweizerisches Rotes Kreuz, Bern, Switzerland.

3 Beckman Instruments, South Pasadena, Calif.
}

all samples and an automatic pistol-type syringe pipette 4 for the delivery of the deproteinizing agent and the reagent mixture. All samples were deproteinized in duplicate, and a duplicate color reaction was carried out for each supernatant fluid. In one experiment, chromatographically pure, uniformly labeled glucose- $\mathrm{C}^{14} 5$ was used. Procedures for isolation and counting of $\mathrm{C}^{14}$-labeled metabolites have been reported elsewhere (30).

Free L-lactic acid was prepared from the calcium salt ${ }^{\circ}$ by passage over a cation exchange resin. L-Lactic acid was determined with lactic dehydrogenase by the test combination set of Boehringer. Palmitic acid was added to concentrated albumin as the potassium salt during heating to $40^{\circ} \mathrm{C}$ and continuous stirring. FFA were determined according to Gordon (33).

Guinea-pig antibeef insulin serum was produced in a manner similar to that of Moloney and Coval (34). Severe hypoglycemic reactions were encountered in guinea pigs when more than $3 \mathrm{U}$ of emulsified insulin ? were administered subcutaneously for the initial injections. Twenty guinea pigs of both sexes were injected at intervals of 2 weeks with increasing amounts of depot insulin, starting with $3 \mathrm{U}$ and attaining ultimately $20 \mathrm{U}$ per injection. After 6 to 8 injections, an antibody titer equivalent to between 0.25 and $0.50 \mathrm{U}$ per $\mathrm{ml}$ serum was obtained. Thereafter, the animals were injected once a month with insulin, and blood was obtained repeatedly by heart puncture 6 to 10 days after the last insulin injection. Several batches of pooled anti-insulin serum of two groups of 20 animals each were used and yielded identical results. The antibody titer was determined by measuring the inhibition of the effects of crystalline pork insulin on pooled epididymal adipose tissue in vitro. The guinea-pig antibeef insulin antibody was shown to possess an electrophoretic mobility of a $\gamma$-globulin, and it could be purified with the conventional ammonium sulfate fractionation without any loss of antiinsulin activity.

Experimental procedure. Anti-insulin serum was added in a concentration of $0.1 \mathrm{ml}$ per $5 \mathrm{ml}$ human serum diluted $1: 5$. The fraction of serum ILA that did not lose its activity when treated with anti-insulin serum was termed "nonsuppressible ILA." Total ILA was measured by treating the serum with the same amount of normal guinea-pig serum instead of anti-insulin serum. Suppressible ILA was obtained by subtracting nonsuppressible ILA from total ILA. No preincubation of the serum with the anti-insulin serum was carried out before the tissue was added. Sera were allowed to stand at room temperature for 20 minutes after thorough mixing with the anti-insulin serum before the tissue was

${ }^{4} \mathrm{We}$ are grateful to Mr. E. Schildknecht, Freilagerstrasse 11, Zürich, for the construction of this pipette. A publication on its performance is in preparation.

5 Radiochemical Center, Amersham, England.

${ }^{6}$ Sigma Chemical Corp., St. Louis, Mo.

${ }^{7} \mathrm{We}$ are indebted to Dr. W. M. Mikulaschek, Eli Lilly and Co., Indianapolis, Ind., for the generous supply of crystalline beef insulin and for the support of this work. 
added for incubation. In each insulin assay, 4 of the 12 available Warburg flasks were used for the incubation of two insulin standard concentrations (10 and 1,000 $\mu \mathrm{U}$ per $\mathrm{ml}$ ). The remaining flasks served for the determination of ILA of two sera in the absence and presence of anti-insulin serum, each in duplicate. The figures of ILA given in the text, tables, and figures represent the mean of the results obtained with the net gas exchange and with the glucose uptake in microunits per milliliter undiluted serum.

Twelve pure-bred male Osborn-Mendel rats weighing between 120 and $180 \mathrm{~g}$ were decapitated after an overnight fast. Care was taken to select 12 rats for each assay whose weight varied less than $20 \mathrm{~g}$. This point needs to be stressed, since large differences in animal or tissue weight tend to nullify the advantage of the pool design used in this assay. The epididymal fat pad was cut at the base. Each side was then dissected into 6 equal pieces, and care was taken to traumatize the tissue as little as possible. If the 12 pieces prepared per rat differed very much in size, however, we did not hesitate to equalize these differences as carefully as possible by further dissections. Each piece was then dropped into one of the 12 Warburg flasks containing $2 \mathrm{ml}$ of incubation medium, and the pieces were distributed so that each flask contained two distal parts, one from the left and one from the right side, two proximal parts from both sides, and so forth. The flasks containing the pooled tissue were kept at room temperature throughout the preparation. The tissue weight was obtained by weighing the flasks on a Mettler balance before and after addition of the tissue.

The preparation of the Warburg flasks to the point of aeration took 20 to 30 minutes. The flasks were treated with a mixture of $95 \% \mathrm{O}_{2}$ and $5 \% \mathrm{CO}_{2}$ for 6 minutes during shaking in a Warburg apparatus (Braun, type $\mathrm{V}$ 85) with a frequency of 96 per minute and an amplitude of $6 \mathrm{~cm}$ at a temperature of $37.5^{\circ} \mathrm{C}$. The flasks were then closed, and manometric readings were taken every 15 or 30 minutes. In order to obtain adequate precision and an increment of net gas exchange that did not change at the end of incubation, the glucose uptake should exceed $20 \%$ (low insulin standard) and remain below $80 \%$ (high insulin standard) of the glucose initially present in the flasks. A glucose uptake within these limits took place during a total incubation period of 2 to 3 hours, depending upon the amount and activity of the tissue used. This may easily be judged during each assay on the basis of the net gas exchange. The incubation was terminated when the positive net pressure change in the flasks containing the high insulin standards reached 250 to $300 \mathrm{~mm}$ (Brodie's solution).

Buffering capacity of incubation media as a function of protein concentration. The net gas exchange of adipose tissue is synonymous with the net change of pres-

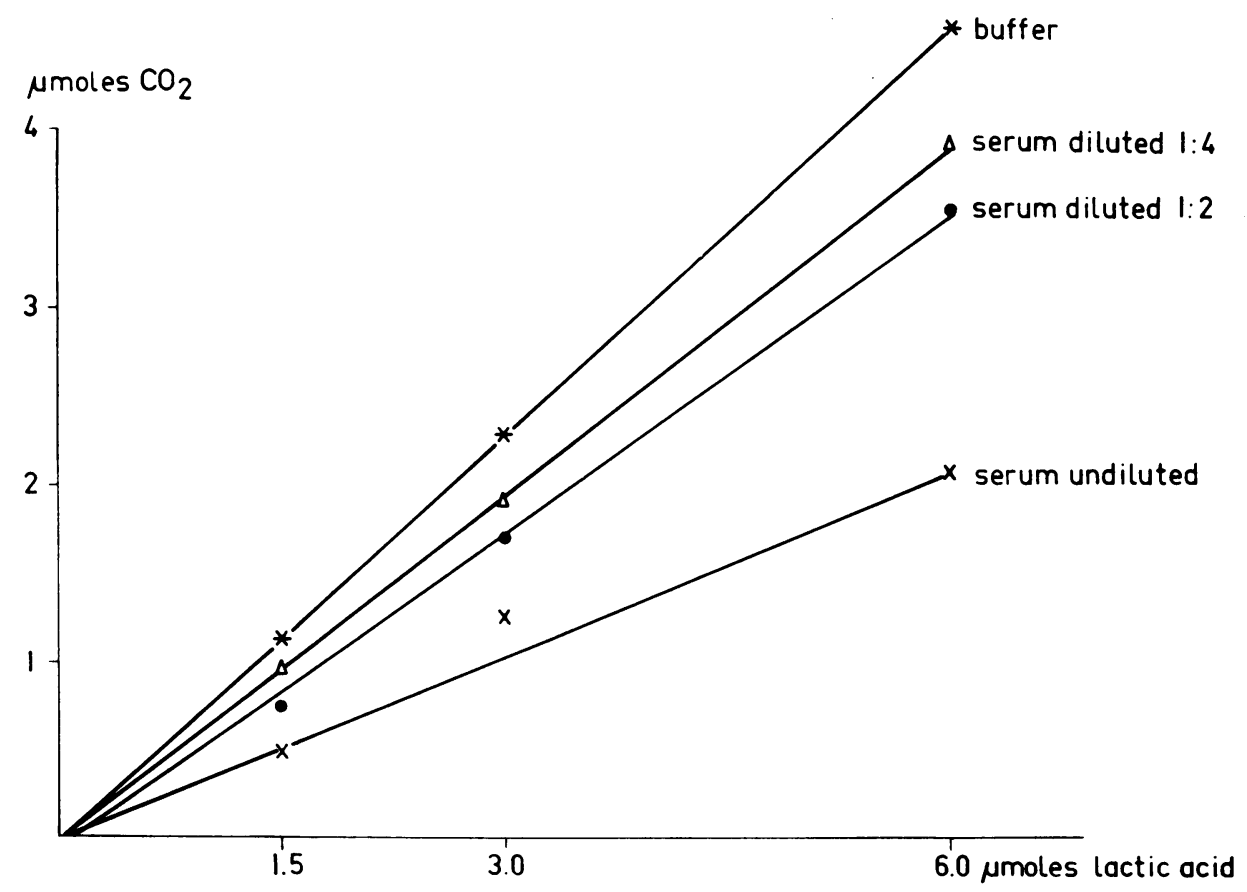

Fig. 1. $\mathrm{CO}_{2}$ RELEASE From incubation medium by addition of Lactic acid as a function OF SERUM PROTEIN CONCENTRATION. Each flask contained $2 \mathrm{ml}$ of medium. $d, l$-Lactic acid was added from the sidearm after aeration with $95 \% \quad \mathrm{O}_{2}$ and $5 \% \mathrm{CO}_{2}$ and after subsequent equilibration lasting 20 minutes. The protein concentration of undiluted serum was $6 \mathrm{~g}$ per $100 \mathrm{ml}$. Every point represents the result of one flask. 


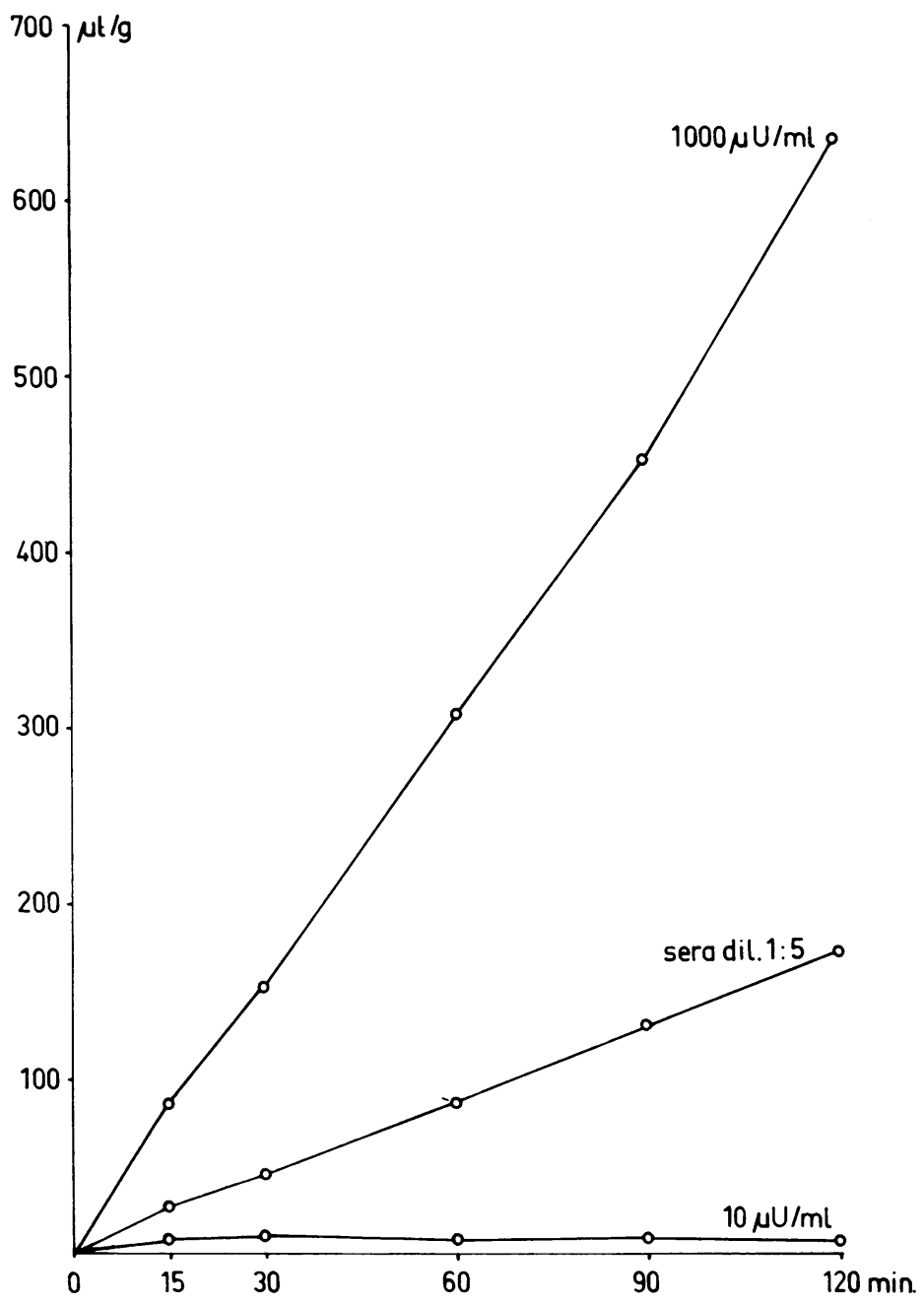

Fig. 2. Net gas exchange as a function of time. The mean evolution of gas exchange of 4 insulin asays, each with 10 and $1,000 \mu \mathrm{U}$ of insulin per $\mathrm{ml}$, and with 2 sera diluted 1:5 are plotted as a function of time. The conditions were those of the standard insulin assay procedure.

sure in a closed system at constant volume resulting from oxygen uptake and $\mathrm{CO}_{2}$ evolution by the tissue. The production of $\mathrm{CO}_{2}$ is a function of the substrate oxidation as well as of the release of $\mathrm{CO}_{2}$ from the medium by organic acid. As shown in Figure 1, $1.5 \mu$ moles lactic acid displaced approximately 0.5 and $1.1 \mu$ moles $\mathrm{CO}_{2}$ from $2 \mathrm{ml}$ undiluted serum and $2 \mathrm{ml} \mathrm{Krebs-Ringer} \mathrm{bi-}$ carbonate buffer, respectively. Between 1.00 and 1.05 $\mu$ moles $\mathrm{CO}_{2}$ were displaced by $1.5 \mu$ moles lactic acid from $2 \mathrm{ml}$ of both $1: 5$ diluted serum and $1.5 \mathrm{~g}$ albumin per $100 \mathrm{ml}$ buffer. In order to have a similar buffering capacity in all media used, sera were therefore diluted $1: 5$, and $1.5 \mathrm{~g}$ albumin per $100 \mathrm{ml}$ was added to the buffer containing the standard concentrations of insulin. This addition of albumin, compared with buffer alone, did not alter basal glucose uptake, net gas exchange, or metabolism of glucose- $\mathrm{C}^{\mathbf{1 4}}$. The effects of insulin on adi- pose tissue were neither inhibited nor potentiated by albumin.

Lactic acid and FFA. In ten insulin assays, the average lactic acid concentration at the end of incubation was $10.1 \pm 4.1 \mathrm{SD}$ and $11.8 \pm 4.4 \mathrm{mg}$ per $100 \mathrm{ml}$ in the presence of 10 and $1,000 \mu \mathrm{U}$ of insulin per $\mathrm{ml}$, respectively. When 1:5 diluted serum served as a medium, the lactic acid concentration was $5.2 \mathrm{mg}$ per $100 \mathrm{ml}$ initially and $10.9 \mathrm{mg}$ per $100 \mathrm{ml}$ at the end of incubation. When lactic acid was added to buffer in varying amounts before incubation, adipose tissue tended to adjust its final concentration to a constant value irrespective of the initial concentration (Table I). Furthermore, the net gas exchange was the same whether lactic acid was being released or taken up by the tissue. Glucose used by the tissue for lactic acid formation appears to be lost for oxidation and fatty acid synthesis, and the metabolic net gas exchange accordingly appears to diminish and to 


\section{GLUCOSE UPTAKE}
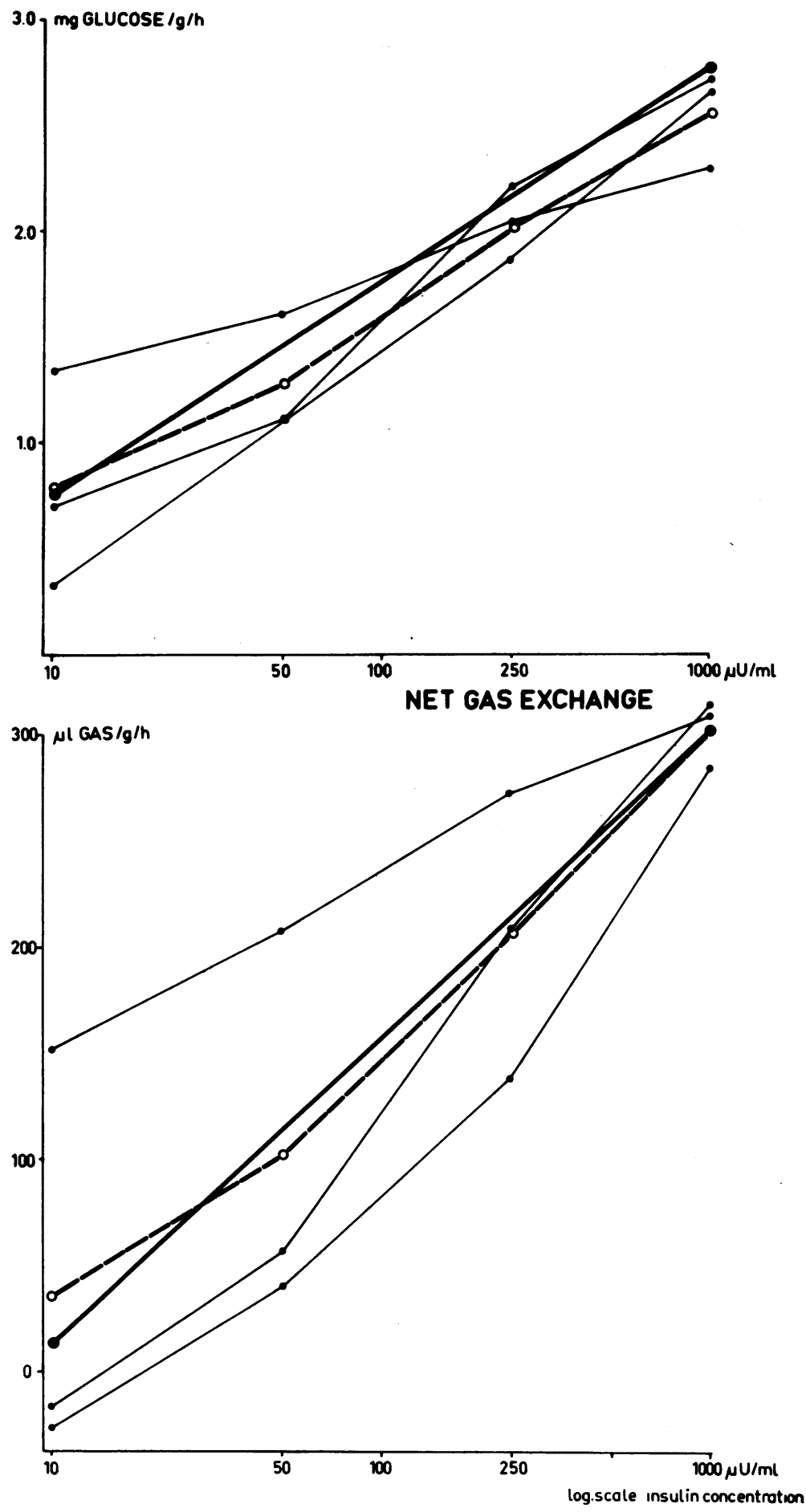

Fig. 3. Insulin standard curves. Three 4-point insulin standard curves each with $10,50,250$, and $1,000 \mu \mathrm{U}$ per $\mathrm{ml}$ (thin lines) and their mean curve (dotted line) are compared with the mean 2-point standard curve of 31 insulin assays with 10 and $1,000 \mu \mathrm{U}$ per $\mathrm{ml}$ (thick line). 
compensate for displacement of $\mathrm{CO}_{2}$ by acid. Raising FFA concentration from 0.47 to $1.72 \mu \mathrm{Eq}$ per $\mathrm{ml}$ by the addition of palmitic acid to the albumin buffer did not significantly affect the glucose uptake $(0.80 \pm 0.08 \mathrm{SD}$ and $0.86 \pm 0.03 \mathrm{mg}$ per $\mathrm{g}$ per hour, $\mathrm{p}>0.40$ ) or the net gas exchange $(-52 \pm 5 \mathrm{SD}$ and $-60 \pm 11 \mu \mathrm{l}$ per $\mathrm{g}$ per hour, $\mathrm{p}>0.10$ ).

Evaluation of glucose uptake and net gas exchange as metabolic indexes of serum ILA. a) Linear evolution of net gas exchange with time. A substantial decrease of the glucose concentration during incubation was inherent in this assay, since the glucose uptake served as a metabolic index. Figure 2 shows the evolution of the net gas exchange of tissue incubated in the presence of insulin and of serum. Although the average glucose concentration in the presence of $1,000 \mu \mathrm{U}$ of insulin per $\mathrm{ml}$ had fallen from 200 to $82 \mathrm{mg}$ per $100 \mathrm{ml}$ at the end of incubation, the net gas exchange remained virtually linear.

b) Insulin standard curves. The regular insulin standard concentrations used routinely were 10 and $1,000 \mu \mathrm{U}$ per $\mathrm{ml}$. In each assay, a pair of standards was run to determine the regression coefficient for each individual assay. Figure 3 shows that the glucose uptake and the net gas exchange were linear functions of the logarithm of the insulin concentrations in the range between 10 and $1,000 \mu \mathrm{U}$ per $\mathrm{ml}$. In Figure 3, the mean standard curve of 31 regular 2-point insulin assays was compared with three 4-point assays $(10,50,250$, and $1,000 \mu \mathrm{U}$ per $\mathrm{ml})$. The mean curve of these 4-point assays was nearly linear for both metabolic indexes and was practically superposable on the mean standard curve of the 2-point assays. Crystalline human insulin yielded standard curves that were superposable on the regular standard curves with crystalline pork insulin.

c) In three recovery experiments summarized in Table II, as little as $25 \mu \mathrm{U}$ per ml diluted serum was regularly detected, and the amount of insulin recovered corresponded to the amount added within the error of this method. No inhibition of the effect of insulin on adipose tissue by serum was observed. In one experiment, insulin was added to serum of a patient in diabetic coma and was quantitatively recovered.
TABLE I

Lactic acid production, glucose uptake, and net gas exchange of pooled epididymal adipose tissue incubated in the presence of varying concentrations of lactic acid*

\begin{tabular}{|c|c|c|c|c|}
\hline $\begin{array}{l}\text { Lactic acid added to medium } \\
\text { before incubation, } \\
m \mathrm{mg} / 100 \mathrm{ml}\end{array}$ & 0.0 & 2.0 & 6.4 & 15.5 \\
\hline $\begin{array}{l}\text { Lactic acid concentration at } \\
\text { the end of incubation, } \\
m g / 100 \mathrm{ml}\end{array}$ & 16.6 & 19.1 & 18.6 & 19.6 \\
\hline Net gas exchange, $\mu l / g /$ hour & 41 & 57 & 48 & 46 \\
\hline Glucose uptake, $m g / g / h o u r$ & 1.78 & 1.86 & 1.95 & 1.87 \\
\hline
\end{tabular}

* L-Lactic acid was added to the medium as the free acid. The mean weight of adipose tissue per flask was $237 \mathrm{mg}$. The 3-hour incubation was carried out in $2 \mathrm{ml}$ buffer containing $200 \mathrm{mg}$ glucose per $100 \mathrm{ml}$ and no protein. Each figure represents the mean of the results of 3 flasks.

d) Statistical analysis ${ }^{8}$ of each assay was carried out separately for each metabolic index. SD was obtained according to the formula $s=\sqrt{\frac{1}{2} \Sigma(a-b)^{2} / n}$, where $a$ and $b$ were the duplicates of the standards and of the unknowns, and $n$ was the number of duplicate determinations, equalling 6 in each regular assay. Thus, SD was obtained from data of sera as well as those of the insulin standards. To find out whether this simplification was justified, SD of each group, i.e., of the two insulin standards and of the sera, was calculated separately on the basis of the data of 28 regular insulin assays in which 104 sera had been tested. On the basis of these results, shown in Table III, we felt justified in poo.ing all data of each assay to arrive at the SD.

As an index of precision, the $\lambda=s / b$ was used, where $b$ was the regression coefficient of the standard curve. The average $b$ for the glucose uptake on the basis of 53 assays was 1.126 and 149.9 for the net gas exchange. The $\lambda$ were 0.140 and 0.113 , respectively. The worst $\lambda$

$8 \mathrm{We}$ are indebted to Dr. C. Zeller for his advice and help with the statistical treatment of the data.

TABLE II

Recovery of crystalline pork insulin added to sera of two normal subjects and one patient in diabetic coma*

\begin{tabular}{ccccc}
\hline \hline Subject & ILA in serum 1:5 & Insulin added & ILA found & Insulin recovered \\
\hline & $\mu U / m l$ & $\mu U / m l$ & $\mu U / m l$ & $\mu U / m l$ \\
Experiment 1 & 87 & 10 & 82 & 0 \\
Normal & 87 & 25 & 154 & 67 \\
& 87 & 50 & 220 & 133 \\
Experiment 2 & 15 & 10 & 17 & 2 \\
Normal & 15 & 25 & 85 & 65 \\
Experiment 3 & 15 & 50 & 12 & 4 \\
Patient in diabetic coma & 8 & 20 & 273 & 265 \\
& 8 & 500 & 815 & 807
\end{tabular}

* The conditions were those of the standard insulin assay procedure. Each figure represents the mean of the results obtained in two flasks by net gas exchange and by glucose uptake. ILA = insulin-like activity. 
TABLE III

Mean results of 28 insulin assays and their standard deviations calculated separately for each standard insulin concentration and for 104 sera diluted 1:5*

\begin{tabular}{|c|c|c|c|c|}
\hline & \multirow[b]{2}{*}{ Units of mean $\pm \mathrm{SD}$} & \multicolumn{2}{|c|}{ Insulin standards } & \multirow[b]{2}{*}{ Sera 1:5 } \\
\hline & & $10 \mu \mathrm{U} / \mathrm{ml}$ & $1,000 \mu \mathrm{U} / \mathrm{ml}$ & \\
\hline Net gas exchange & $\begin{array}{l}\mu \mathrm{l} / \mathrm{g} / \text { hour } \\
\mu \mathrm{U} / \mathrm{ml}\end{array}$ & $\begin{array}{l}12 \pm 9 \\
10 \pm 1.5 \\
1.3\end{array}$ & $\begin{aligned} 309 & \pm 17 \\
1,000 & \pm 310 \\
& 230\end{aligned}$ & $\begin{array}{l}99 \pm 20 \\
39 \pm 14 \\
11\end{array}$ \\
\hline Glucose uptake & $\begin{array}{l}\mathrm{mg} / \mathrm{g} / \text { hour } \\
\mu \mathrm{U} / \mathrm{ml}\end{array}$ & $\begin{array}{c}0.87 \pm 0.10 \\
10 \pm 2.2 \\
1.8\end{array}$ & $\begin{array}{r}3.20 \pm 0.17 \\
1,000 \pm 390 \\
290\end{array}$ & $\begin{array}{c}1.57 \pm 0.15 \\
40 \pm 14 \\
10\end{array}$ \\
\hline
\end{tabular}

* SD was calculated according to the formula $s=\sqrt{\frac{1}{2} \Sigma(a-b)^{2} / n}$, where $a$ and $b$ are the duplicate determinations and $n$ the number of duplicates $(n=28$ and 104 , respectively). The values of serum ILA are not corrected for dilution, and must be multiplied by five for values of ILA in undiluted serum.

was 0.283 for the glucose uptake, and only 9 times out of 53 did it exceed 0.200 . In the case of the net gas exchange, the $\lambda$ exceeded 0.200 only in one assay. Thus, the net gas exchange seemed to be a somewhat more precise measurement. The results of ILA were always expressed as the average activity obtained with both parameters. The results of the two metabolic indexes were not given a weight reciprocal to their $\lambda$.

Effect of dilution on serum ILA. The net gas exchange regularly yielded results of ILA in undiluted serum that were approximately five times smaller than would have been expected from incubation experiments with $1: 5$ diluted serum (Table IV). Contrary to this, results of ILA obtained with glucose uptake were proportional to the serum dilution. Therefore, the oxidation of uniformly labeled glucose- $\mathrm{C}^{14}$ to $\mathrm{C}^{14} \mathrm{O}_{2}$ and its incorporation into the tissue fatty acids were determined in addition to glucose uptake and net gas exchange. Figure 4 shows a typical experiment in which all metabolic indexes other than net gas exchange yielded values of ILA proportional to the serum dilution.

The dilution effect of serum was reproduced with albumin as the only protein present in the medium. In the presence of $100 \mu \mathrm{U}$ of insulin per $\mathrm{ml}$, the net gas exchange was 23 and $127 \mu \mathrm{l}$ per $\mathrm{g}$ per hour in buffer con- taining $6 \mathrm{~g}$ albumin and $200 \mathrm{mg}$ gelatin per $100 \mathrm{ml}$, respectively (Figure 5). This effect of $100 \mu \mathrm{U}$ insulin per $\mathrm{ml}$ in the high-protein medium corresponded to that of $25 \mu \mathrm{U}$ in the low-protein medium. The dilution effect increased as the insulin concentration rose, and upon extrapolation to $200 \mu \mathrm{U}$ per $\mathrm{ml}$, the difference would have become approximately fivefold and thus would have corresponded to the dilution effect observed in undiluted serum as against that in serum diluted $1: 5$.

Effects of anti-insulin serum. ILA of normal and of anti-insulin guinea-pig serum was found to be below $10 \mu \mathrm{U}$ per ml. No effect on basal glucose uptake and net gas exchange of adipose tissue was detected when these sera were diluted $1: 50$ as in the assay procedure. Antibeef insulin guinea-pig serum inhibited the action of crystalline insulin on adipose tissue entirely and inhibited human insulin as effectively as pork insulin. The effects of crystalline human insulin preincubated with human serum were also completely suppressed by antiinsulin serum (Table V). Therefore, one would expect that the effects of endogenous insulin would also be inhibited by anti-insulin serum if it were present in serum in the same state as dissolved crystalline insulin. Tables V and VI show that the metabolic indexes of serum ILA were only partially inhibited in the presence

TABLE IV

The effect of serum dilution on ILA*

\begin{tabular}{|c|c|c|c|c|c|c|c|c|}
\hline \multirow[b]{2}{*}{ ILA measurement } & \multicolumn{7}{|c|}{ Serum dilution } & \multirow[b]{2}{*}{ Exp't no } \\
\hline & $1: 1$ & $1: 2.5$ & $1: 5$ & $1: 10$ & $1: 12.5$ & $1: 20$ & $1: 25$ & \\
\hline Glucose uptake & $\begin{array}{l}759 \\
550 \\
933 \\
125\end{array}$ & 1,065 & $\begin{array}{l}830 \\
425 \\
645 \\
165\end{array}$ & 446 & $\begin{array}{l}735 \\
475\end{array}$ & 210 & $\begin{array}{l}959 \\
387\end{array}$ & $\begin{array}{l}1 \\
2 \\
3 \\
4\end{array}$ \\
\hline Net gas exchange & $\begin{array}{r}110 \\
166 \\
151 \\
33\end{array}$ & 600 & $\begin{array}{l}630 \\
485 \\
965 \\
155\end{array}$ & 446 & $\begin{array}{l}750 \\
413\end{array}$ & 176 & $\begin{array}{l}887 \\
425\end{array}$ & $\begin{array}{l}1 \\
2 \\
3 \\
4\end{array}$ \\
\hline
\end{tabular}

* ILA determined in the diluted sera was multiplied by the respective dilution, and all results are expressed in microunits per milliliter of undiluted serum. Each figure represents the mean of the results of two flasks. 

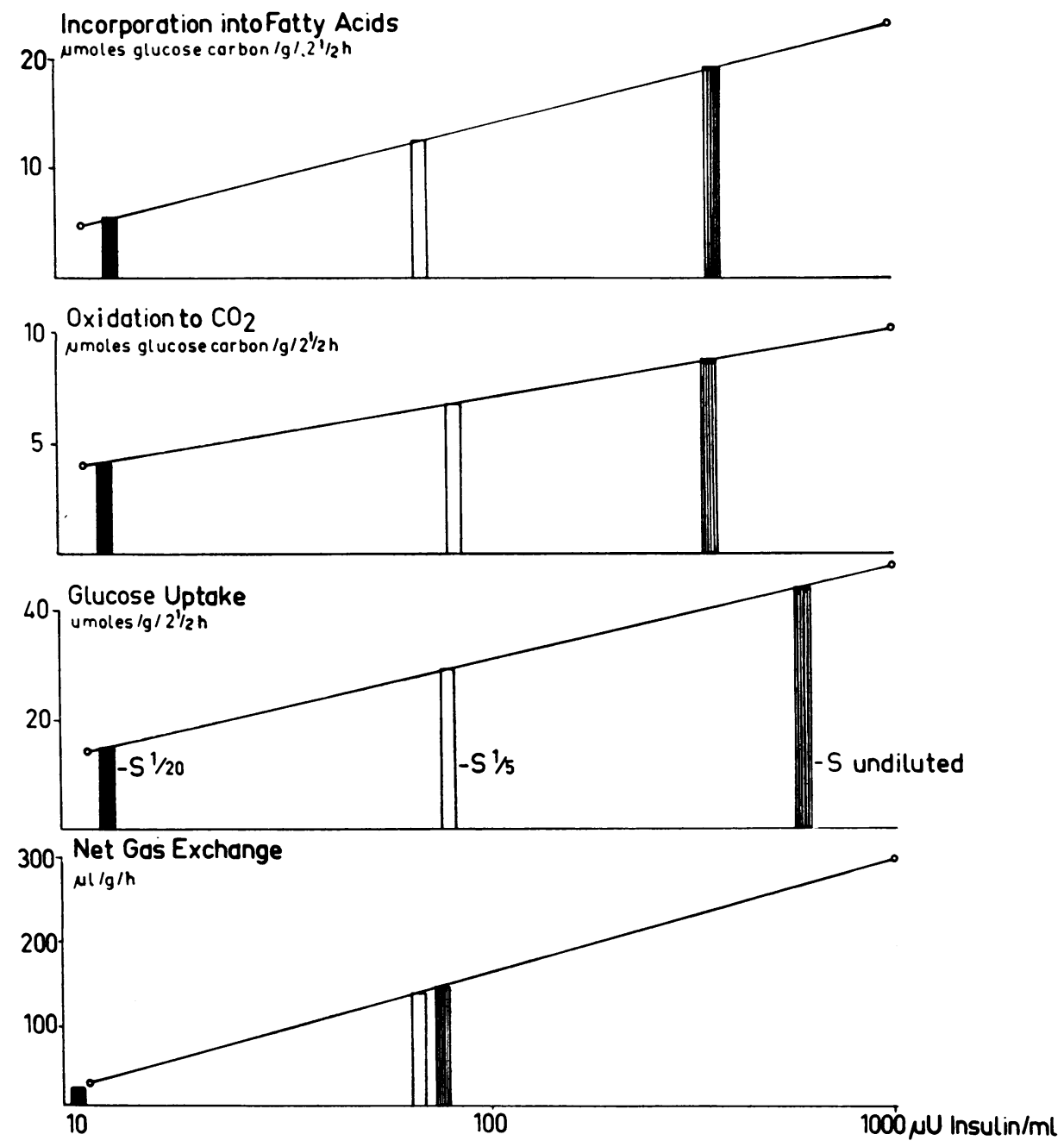

Fig. 4. Simultaneous measurement of 4 metabolic indexes of ILA in UNdiluted SeRUM AND IN SERA DILUTED 1:5 AND 1:20. Incubation was carried out with $1.6 \mu \mathrm{C}$ uniformly labeled glucose- $\mathrm{C}^{14}$ per flask. Oxidation of the glucose- $\mathrm{C}^{14}$ to $\mathrm{C}^{14} \mathrm{O}_{2}$ and its incorporation into the tissue fatty acids were measured as well as glucose uptake and net gas exchange. Values of serum incubations were correlated with those given by the two standard insulin concentrations. Thus, results of serum ILA obtained with the listed metabolic indexes may be compared as a function of serum concentration on the abscissa.

of anti-insulin serum and that they were not further suppressed by an increase in the amount of anti-insulin serum from 0.025 to $0.200 \mathrm{ml}$ per $\mathrm{ml}$ human serum.
Figure 6 shows the kinetic measurement of the net gas exchange of adipose tissue incubated in serum in the presence and absence of anti-insulin serum. The net gas

TABLE V

Inhibition of effects of human crystalline insulin preincubated for 2 hours with buffer or diluted human serum by anti-insulin serum*

\begin{tabular}{|c|c|c|c|c|c|c|c|c|}
\hline Medium & \multicolumn{4}{|c|}{ Buffer } & \multicolumn{4}{|c|}{ Serum 1:5 } \\
\hline Insulin, $\mu U / m l$ & \multicolumn{2}{|c|}{10} & \multicolumn{2}{|c|}{1,000} & \multicolumn{2}{|c|}{10} & \multicolumn{2}{|c|}{1,000} \\
\hline Anti-insulin serum, $0.02 \mathrm{ml} / \mathrm{ml}$ & - & + & - & + & - & + & - & + \\
\hline $\begin{array}{l}\text { Glucose uptake, } \mathrm{mg} / \mathrm{g} / \mathrm{h} \text { our } \\
\text { Net gas exchange, } \mu \mathrm{l} / \mathrm{g} / \mathrm{hour}\end{array}$ & $\begin{array}{r}0.68 \\
-5\end{array}$ & $\begin{array}{l}0.66 \\
-33\end{array}$ & $\begin{array}{l}3.26 \\
+312\end{array}$ & $\begin{array}{l}0.81 \\
-38\end{array}$ & $\begin{array}{c}1.35 \\
+675\end{array}$ & 1.09 & 3.23 & $\begin{array}{r}0.95 \\
+7\end{array}$ \\
\hline
\end{tabular}

* Each figure represents the mean of the results of two flasks. 


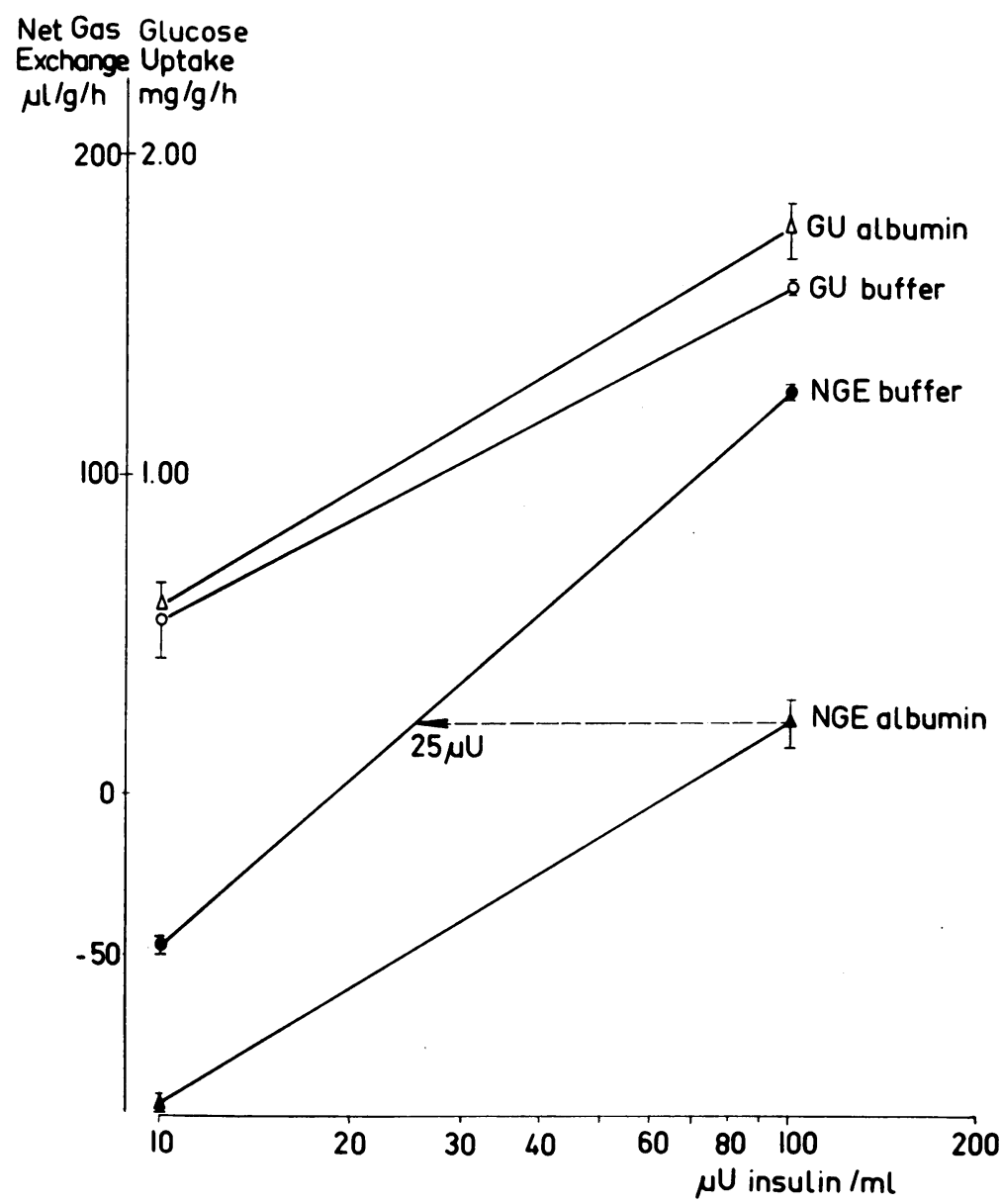

Fig. 5. EFFECT of ALbUMin on glucose UPTAKE AND NET GaS EXChange OF POOLED EPIDIDYMAL ADIPOSE TISSUE IN THE PRESENCE OF 10 AND $100 \mu \mathrm{U}$ INSULIN PER ML. The medium consisted of Krebs-Ringer bicarbonate buffer containing $200 \mathrm{mg}$ gelatin (circles) or $6 \mathrm{~g}$ albumin (triangles) per $100 \mathrm{ml}$. All other conditions were those of the standard insulin assay. Each point represents the mean result of two flasks, and the brackets indicate the range.

exchange increased as a linear function of time, which indicated that the concentration of suppressible and nonsuppressible ILA did not change from the beginning to the end of incubation. When adipose tissue was incubated in the presence of crystalline insulin, the insulin effect on net gas exchange ceased shortly after addition of the antibody (Figure 7).

\section{RESULTS}

Anti-insulin serum suppressible and nonsuppressible ILA in human sera of fasting normal subjects. In 22 sera of normal fasting subjects, ILA was determined with and without the addition of anti-insulin serum. Total ILA was 180 $\mu \mathrm{U}$ per ml, with a range from 68 to $587 \mu \mathrm{U}$ per ml. By far the greater portion of ILA was not suppressed by anti-insulin serum. Suppressible ILA averaged $13 \mu \mathrm{U}$ per $\mathrm{ml}$ and ranged from 0 to $93 \mu \mathrm{U}$ per $\mathrm{ml}$. In three instances, ILA was greater in the presence of anti-insulin serum than in the presence of normal guinea-pig serum, yielding negative values for suppressible ILA. The amount of suppressible ILA usually lay within the error of the method and was significantly greater than 0 only once. When the entire group of the results of suppressible ILA in fasting normal subjects was submitted to an analysis of variance, a significant value for suppressible ILA ( $p<$ 0.01) was obtained with both metabolic indexes. 
TABLE VI

Effect of varying amounts of anti-insulin serum on glucose uptake and net gas exchange of adipose tissue incubated in diluted serum*

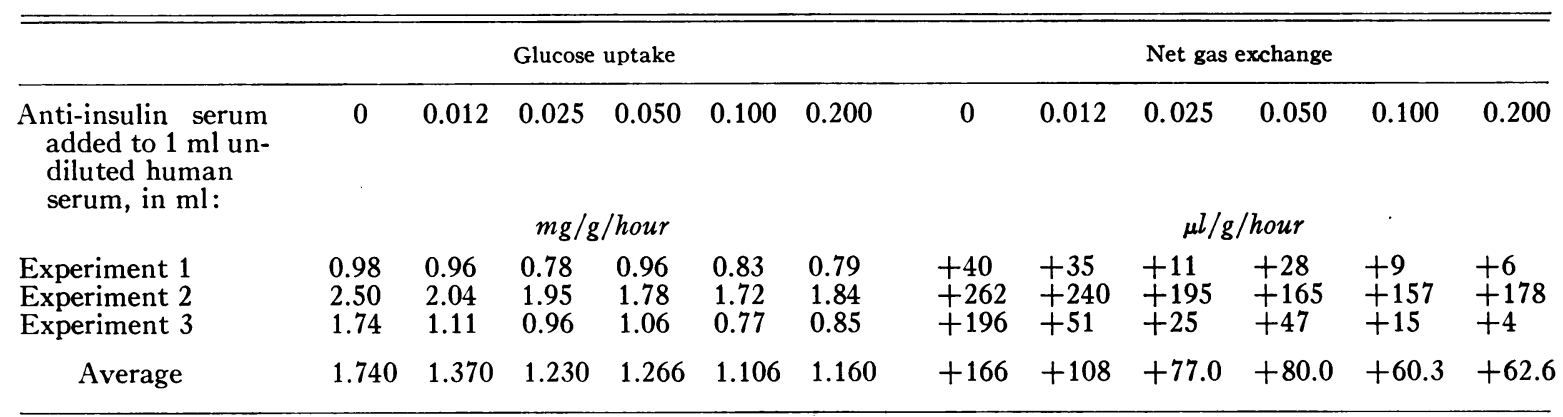

* Each figure represents the mean of the results of two flasks.

Serum ILA after iv administration of regular insulin. Between 0.1 and $0.6 \mathrm{U}$ per $\mathrm{kg}$ body weight of regular insulin Novo representing a mixture of beef and pork insulin was injected intravenously into four normal subjects, and suppressible and nonsuppressible ILA were determined at intervals of 7 to 60 minutes after injection (Table VII). A rise of suppressible ILA was demonstrable for a period up to 15 minutes. The mean suppressible ILA rose from 102 to $2,728 \mu \mathrm{U}$ per $\mathrm{ml} 7$ minutes after insulin injection. Nonsuppressible ILA, however, stayed at the base-line level.

Effect of glucose administration to normal subjects on suppressible and nonsuppressible ILA. Glucose, $100 \mathrm{~g}$, was administered orally to five metabolically normal fasting subjects. As shown in Figure 8, suppressible ILA rose from an average of 13 to $111 \mu \mathrm{U}$ per $\mathrm{ml}$. This rise was statistically highly significant $(p<0.001)$ when the group data were submitted to an analysis of variance. Nonsuppressible ILA did not show any consistent change, and its mean activity was 122 before and $131 \mu \mathrm{U}$ per ml after glucose administration. In five normal subjects infused with $1 \mathrm{~g}$ of glucose per $\mathrm{kg}$ body weight per hour for 2 hours, suppressible ILA rose from an average fasting value of 33 to $285 \mu \mathrm{U}$ per $\mathrm{ml} 2$ hours after the beginning of the glucose infusion, when the mean blood sugar was $282 \mathrm{mg}$ per $100 \mathrm{ml}$. This increase of suppressible ILA was again statistically significant $(p<0.01)$. Nonsuppressible ILA showed an insignificant rise from 157 to $214 \mu \mathrm{U}$ per $\mathrm{ml}$.

Suppressible and nonsuppressible ILA in patients with active $\beta$-islet-cell adenoma. Twentytwo sera of six patients with active $\beta$-islet-cell adenoma were examined. As Figure 9 shows, the range of total ILA in these patients was very broad and extended from 142 to $2,860 \mu \mathrm{U}$ per

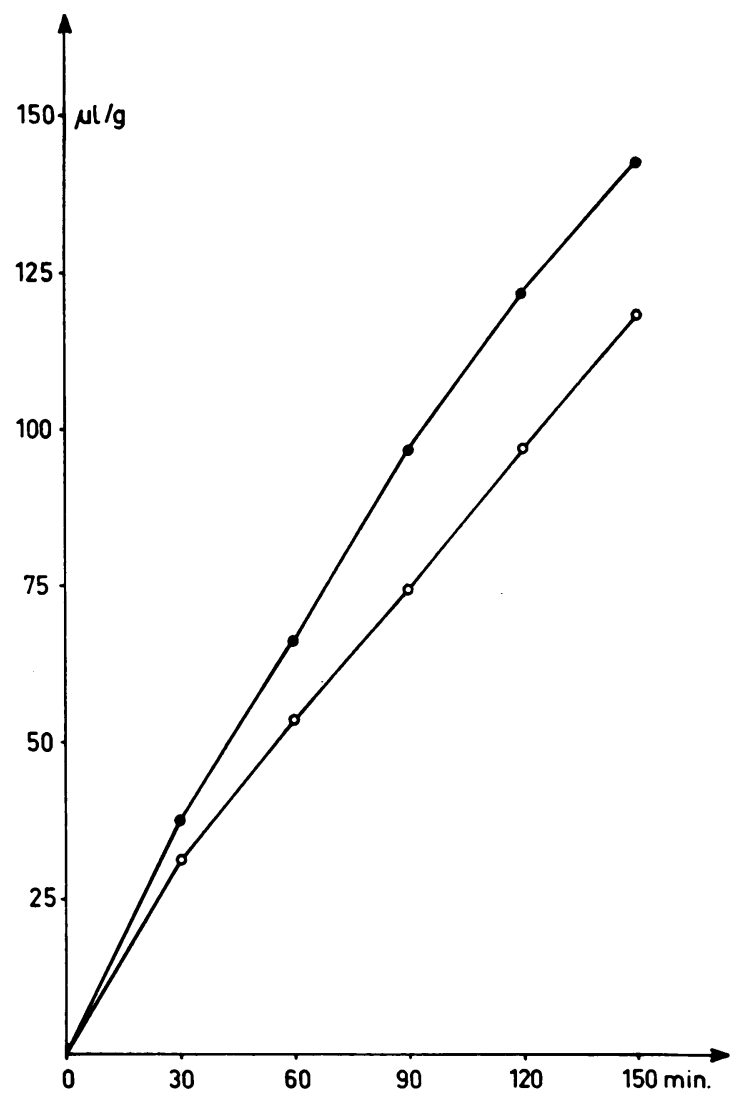

Fig. 6. Net gas eXchange of Adipose tissue inCUBATED IN DILUTED HUMAN SERUM WITH AND WITHOUT ANTI-INSULIN SERUM. Values represent the mean of 8 experiments; $0.02 \mathrm{ml}$ of normal guinea-pig serum (solid circles) or anti-insulin (open circles) was present per $1 \mathrm{ml}$ diluted human serum. The experimental conditions were those of the standard insulin assay. 


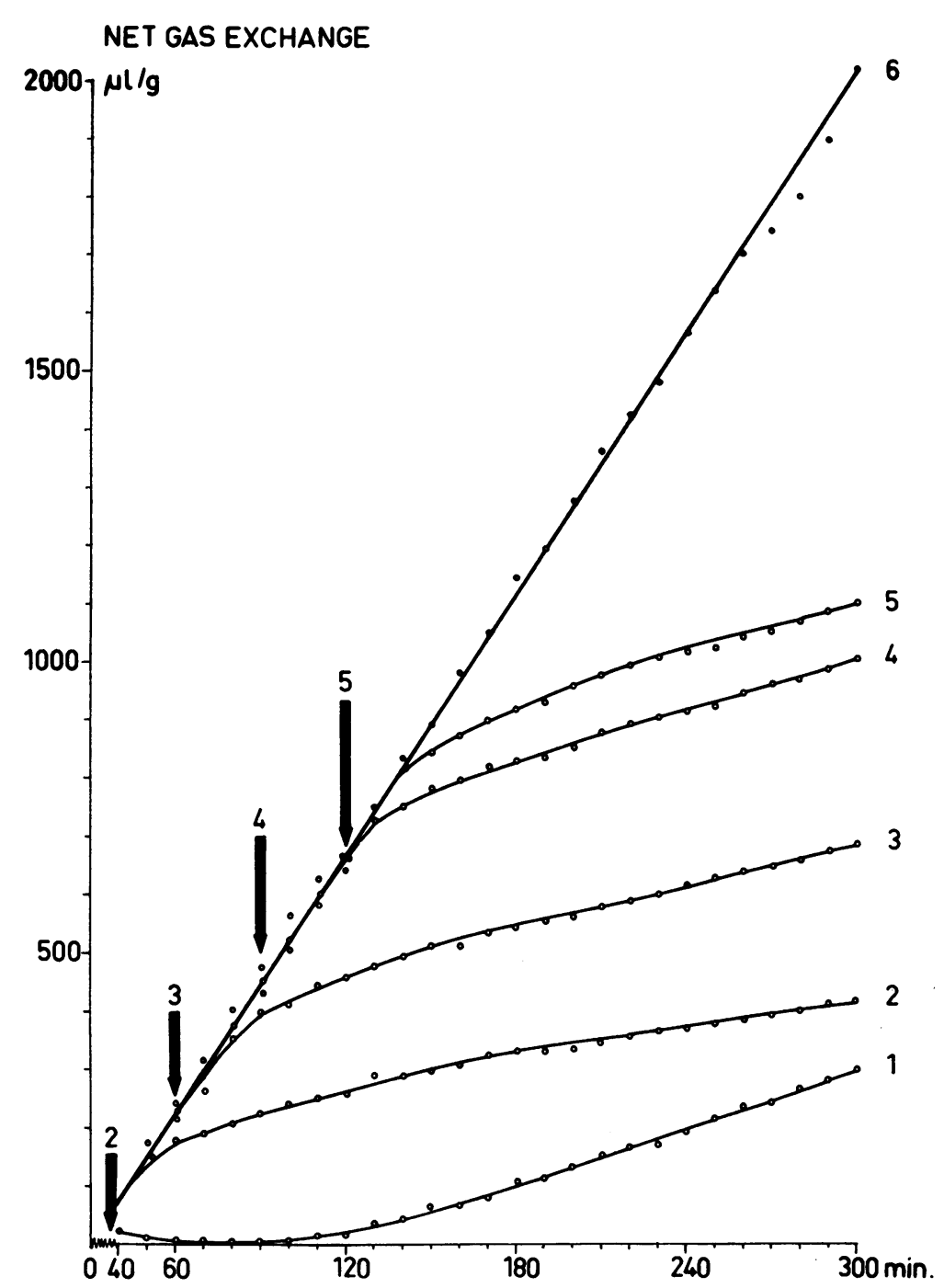

Fig. 7. EFFect of addition of ANTi-InSUlin SERUM at various times FROM THE BEGINNING OF AN INCUBATION OF POOLED ADIPOSE TISSUE IN THE PRESENCE OF $500 \mu \mathrm{U}$ OF CRYSTALLINE INSULIN PER ML. No insulin was present in flask no. 1. Arrows indicate the time of the tilting of the sidearm of the Warburg flasks, and numbers designate the corresponding flasks. Each point represents the mean of the results of two flasks.

ml. The overlap with the range of ILA of normal fasting subjects was considerable. In Figure 10 , the results of suppressible ILA were plotted in the same way. Suppressible ILA in these six patients with $\beta$-islet-cell adenoma ranged from 0 to $2,820 \mu \mathrm{U}$ per $\mathrm{ml}$, and the mean value of the six patients was $252 \mu \mathrm{U}$ per ml. In 10 out of 15 sera and in four out of six patients, a significant amount of suppressible ILA was found, which contrasted with the data in normal fasting subjects, where a significant amount of suppres- sible ILA was usually not detectable in individual sera. In patient K.A., no suppressible ILA was detected in two sera tested. An L-leucine tolerance test with $0.15 \mathrm{~g}$ per $\mathrm{kg}$ was carried out in this patient. Suppressible ILA rose from 0 to $209 \mu \mathrm{U}$ per $\mathrm{ml}$ within an hour after leucine administration. In another patient (B.A.), suppressible ILA rose from 190 to $595 \mu \mathrm{U}$ per $\mathrm{ml}$ at a time when the blood sugar fell from 72 to $29 \mathrm{mg}$ per $100 \mathrm{ml}$. In normal subjects, the same dose of L-leucine was without any effect on blood sugar and sup- 
TABLE VII

Suppressible and nonsuppressible ILA in serum of normal subjects before and after iv administration of regular insulin*

\begin{tabular}{|c|c|c|c|c|c|c|c|}
\hline \multirow[b]{2}{*}{ ILA } & \multicolumn{5}{|c|}{ Minutes after insulin injection } & \multirow[b]{2}{*}{ Insulin dose } & \multirow[b]{2}{*}{ Exp't no. } \\
\hline & $\mathbf{0}$ & 7 & 15 & 30 & 60 & & \\
\hline Suppressible & $\begin{array}{r}124 \\
33 \\
240 \\
11\end{array}$ & $\begin{array}{r}1,006 \\
3,311 \\
783 \\
5,812\end{array}$ & $\begin{array}{r}\mu U / m l \\
206 \\
2,102 \\
130\end{array}$ & $\begin{array}{r}115 \\
0\end{array}$ & $\begin{array}{r}30 \\
0\end{array}$ & $\begin{array}{c}U / k g \text { body wt } \\
0.10 \\
0.15 \\
0.20 \\
0.60\end{array}$ & $\begin{array}{l}1 \\
2 \\
3 \\
4\end{array}$ \\
\hline Nonsuppressible & $\begin{array}{r}241 \\
84 \\
247 \\
104\end{array}$ & $\begin{array}{r}296 \\
91 \\
342 \\
100\end{array}$ & $\begin{array}{l}189 \\
123 \\
177\end{array}$ & 165 & $\begin{array}{l}175 \\
190\end{array}$ & $\begin{array}{l}0.10 \\
0.15 \\
0.20 \\
0.60\end{array}$ & $\begin{array}{l}1 \\
2 \\
3 \\
4\end{array}$ \\
\hline
\end{tabular}

* The experimental conditions were those of the standard insulin assay. The subjects in experiments 1 and 3 were not fasting and therefore had high initial values for suppressible ILA.

pressible ILA. Nonsuppressible ILA in the same six patients with $\beta$-islet-cell adenoma ranged from 41 to $322 \mu \mathrm{U}$ per ml, with a mean of 184 .

Suppressible and nonsuppressible ILA in patients with diabetes mellitus. The results obtained in 18 patients with maturity onset diabetes ${ }^{9}$ are summarized in Table VIII and Figure 11. After

9 All patients with diabetes mellitus referred to in this paper had never been treated with insulin or oral antidiabetic drugs.

Non Suppressible ILA

$\mu \mathrm{U} / \mathrm{ml}$ serum

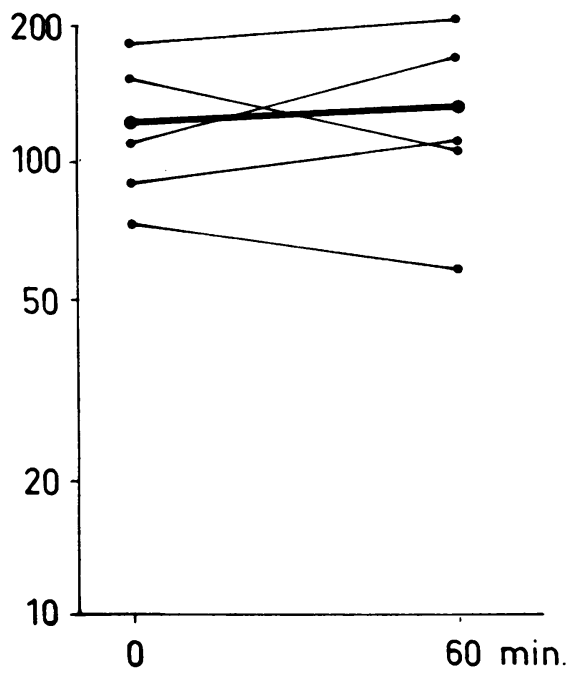

an overnight fast and at a mean blood sugar of $165 \mathrm{mg}$ per $100 \mathrm{ml}$, suppressible ILA was higher than in the normal fasting subjects and amounted to $49 \mu \mathrm{U}$ per ml. Nonsuppressible ILA was somewhat lower $(130 \mu \mathrm{U}$ per $\mathrm{ml})$ than in the normal subjects, but the difference was statistically not significant. Ten juvenile diabetic subjects ${ }^{9}$ with recent onset who had a mean blood sugar of $299 \mathrm{mg}$ per $100 \mathrm{ml}$ and, generally, a moderate degree of ketonemia exhibited increased sup-

\section{Suppressible II A}

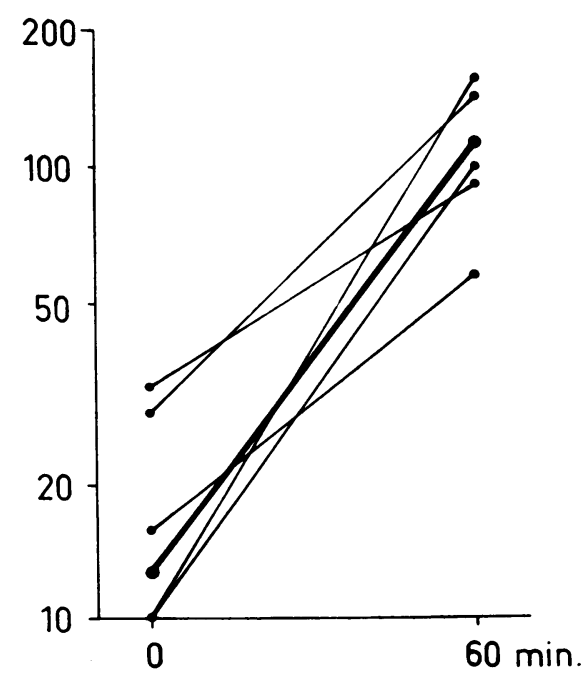

Fig. 8. NONSUPPRESSIBLE AND SUPPRESSIBLE ILA IN 5 NORMAL SUBJECTS AFTER AN OVERNIGHT FAST AND 1 HOUR AFTER $100 \mathrm{~g}$ OF ORAL GLUCOSE. The thick line represents the mean of the 5 individual curves. 


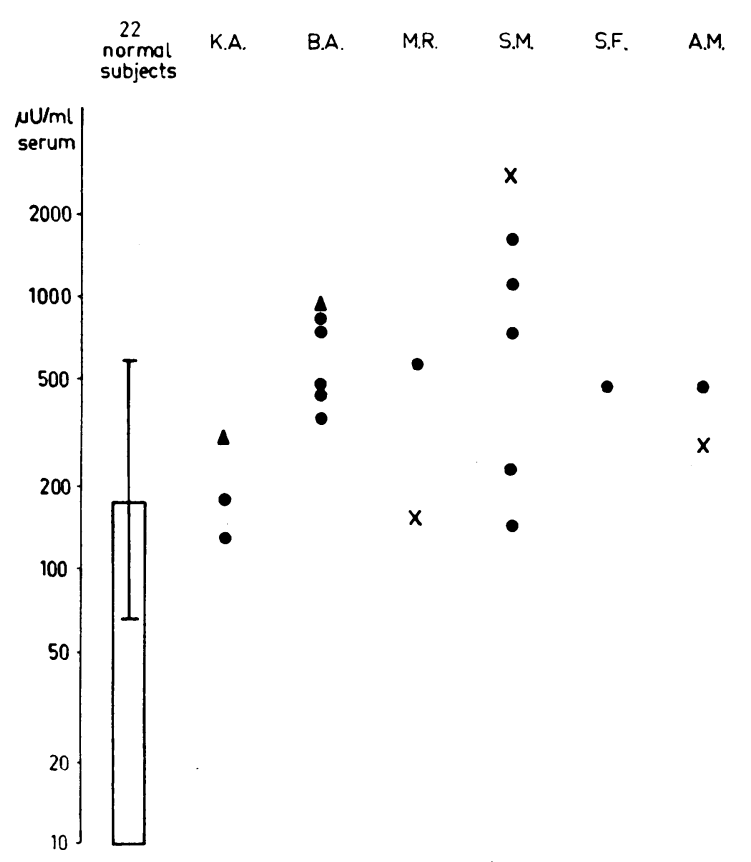

Fig. 9. Total ILA in 22 Normal subJects AND in 6 patients with active $\beta$-islet-cell adenoma. The height of the column designates the average value, and the bracket, the range of total ILA in normal subjects. 0 , after an overnight fast; $\times$, during hypoglycemic attacks; and $\Delta$, after $0.15 \mathrm{~g}$ of oral L-leucine per $\mathrm{kg}$ body weight.

pressible ILA of $44 \mu \mathrm{U}$ per ml. Suppressible ILA of normal subjects, however, after iv glucose administration and at comparable blood glucose levels, was significantly higher than that in juvenile diabetics $(p<0.001)$. In seven patients in diabetic coma, ${ }^{9}$ suppressible ILA was absent at an average blood sugar of $895 \mathrm{mg}$ per $100 \mathrm{ml}$. Nonsuppressible ILA was normal. When the blood sugar was correlated with suppressible ILA (Figure 11), a highly significant correlation coeffi-

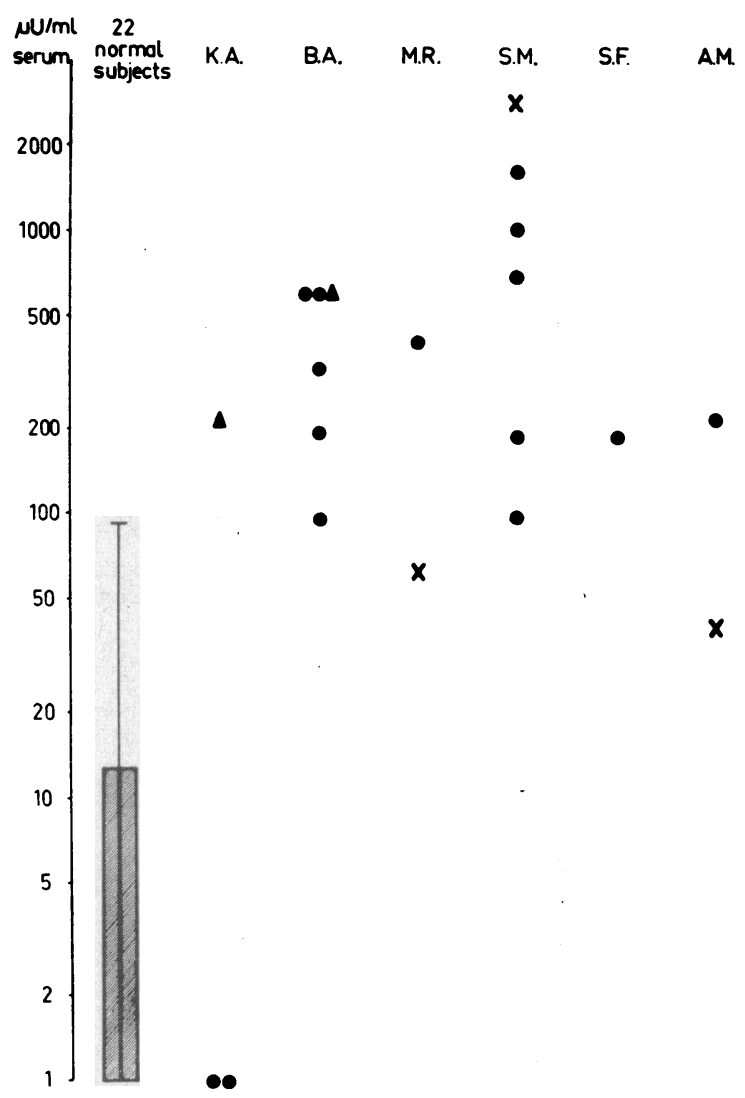

Fig. 10. SUPPressible ILA in 22 NORMal subjects AND IN 6 PATIENTS WITH ACTIVE $\beta$-ISLET-CELL ADENOMA. The height of the column designates the average value, and the bracket, the range of suppressible ILA in normal subjects. 0 , after an overnight fast; $\times$, during hypoglycemic attacks; and $\boldsymbol{\Delta}$, after $0.15 \mathrm{~g}$ of oral L-leucine per $\mathrm{kg}$ body weight.

cient $(r=0.734, p<0.001)$ was found in the normal subjects. In contrast to this, there seemed to be no correlation between suppressible ILA and blood sugar in 28 patients with diabetes mellitus $(\mathrm{r}=0.240, \mathrm{p}>0.10)$.

TABLE VIII

Total, nonsuppressible, and suppressible ILA in normal fasting subjects and in patients with diabetes mellitus*

\begin{tabular}{|c|c|c|c|c|c|c|c|}
\hline \multirow[b]{2}{*}{ Subjects } & \multirow[b]{2}{*}{ Blood glucose } & \multicolumn{6}{|c|}{ Insulin-like activity } \\
\hline & & Total & $\mathrm{p}<$ & $\begin{array}{c}\text { Non- } \\
\text { suppressible }\end{array}$ & $\mathrm{p}<$ & Suppressible & $\mathrm{p}<$ \\
\hline & $\mathrm{mg} / 100 \mathrm{ml}$ & $\mu U / m l$ & & $\mu U / m l$ & & $\mu U / m l$ & \\
\hline 22 Normal, fasting & 87 & 181 & & 168 & & 13 & \\
\hline 18 Maturity-onset diabetic & 165 & 179 & 0.47 & 130 & 0.25 & 49 & 0.10 \\
\hline 10 Juvenile diabetic & 299 & 143 & 0.25 & 99 & 0.10 & 44 & 0.05 \\
\hline 7 In diabetic coma & 895 & 164 & 0.35 & 186 & 0.35 & 0 & 0.10 \\
\hline
\end{tabular}

* All patients with diabetes mellitus, including those in diabetic coma, had never been treated with insulin or oral antidiabetic drugs. Values of $\mathrm{p}$ are those analyzed against values in normal subjects. 


\section{SUPPRESSIBLE ILA}

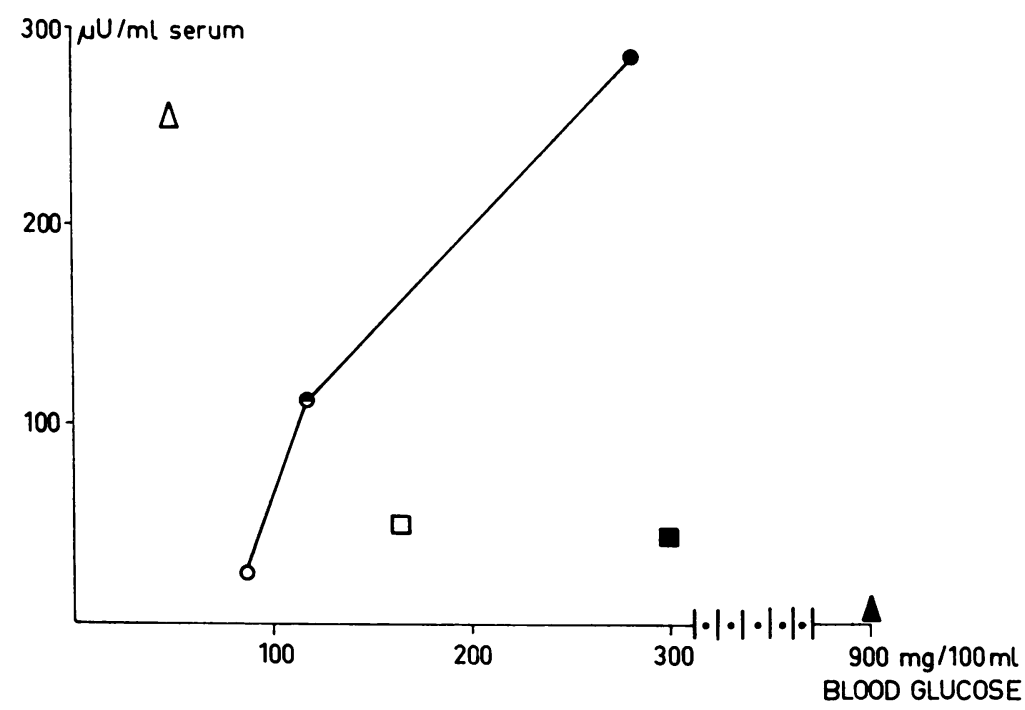

Fig. 11. Correlation of suppressible ILA with blood glucose. O, fasting value ( 9 normal subjects); $\Theta, 1$ hour after $100 \mathrm{~g}$ of oral glucose ( 5 normal subjects); $\bullet, 2$ hours after the start of a glucose infusion with $1 \mathrm{~g}$ per $\mathrm{kg}$ per hour ( 4 normal subjects) ; $\Delta, 6$ patients with active $\beta$-isletcell adenoma; $\square, 18$ patients with maturity-onset diabetes; $\mathbf{\square}, 10$ patients with juvenile-onset diabetes; and $\boldsymbol{\Lambda}, 7$ patients in diabetic coma.

Comparison of effects of crystalline insulin with those of the two forms of serum ILA. The mean ILA of 104 sera diluted 1:5 was $40 \mu \mathrm{U}$ per ml measured by glucose uptake and $39 \mu \mathrm{U}$ per $\mathrm{ml}$ by net gas exchange (Table III). Values of net gas exchange of 26 insulin assays comprising data

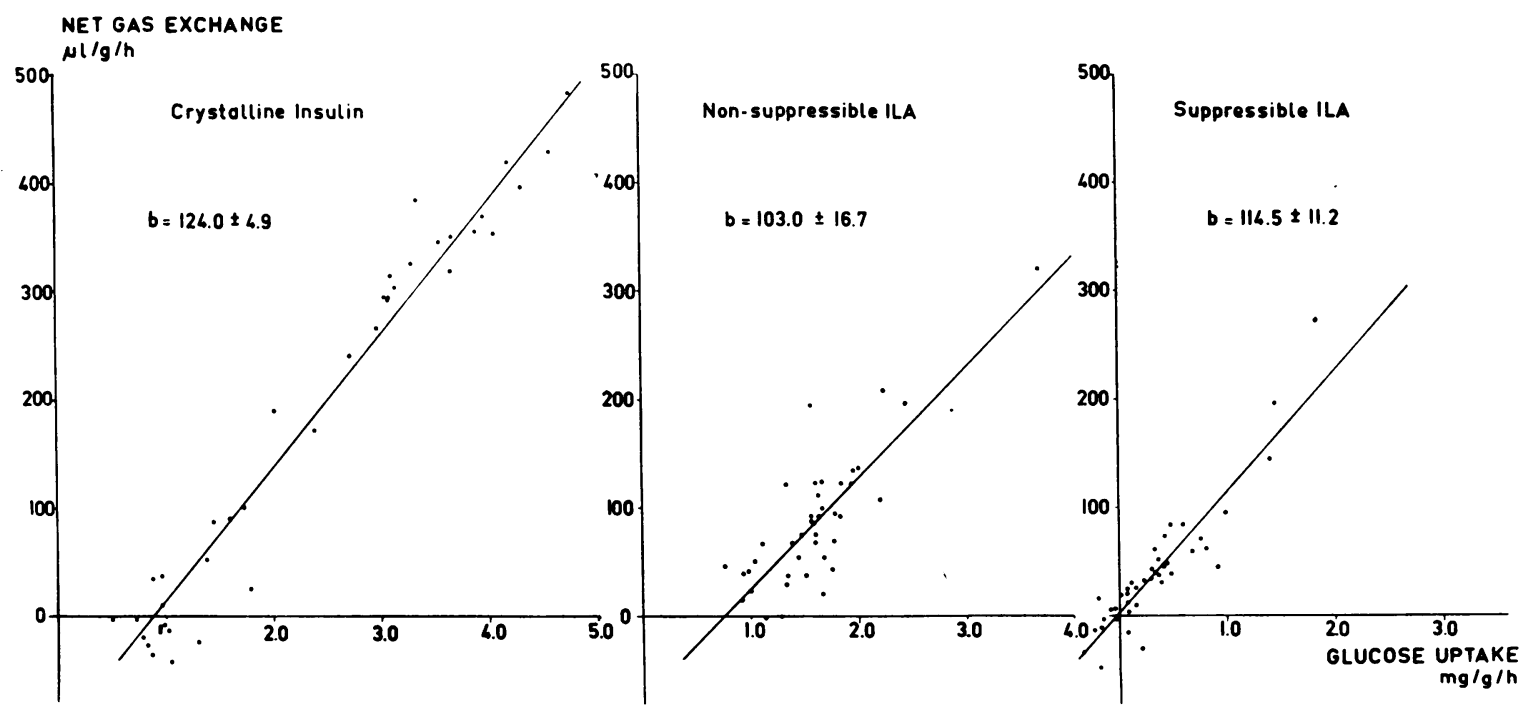

Fig. 12. Correlation of glucose uptake and Net gas exchange of adipose tissue under the influence of CRYSTALLINE PORK INSULIN, NONSUPPRESSIBLE AND SUPPRESSIBLE HUMAN SERUM ILA. Data were used of 20 insulin assays in which ILA of 40 sera diluted 1:5 was determined. $b=$ regression coefficient of $y$ upon $x$ with $\mathrm{SD}$. The 3 regression coefficients do not differ significant'y from each other. All 3 regressions show a highly significant correlation coefficient $(\mathrm{p}<0.001)$. The regression line of suppressible ILA passes through the point of interception of the coordinates, since an increment of the metabolic effects above those produced by nonsuppressible ILA is plotted. 
on 102 sera were correlated with those of the glucose uptake for the insulin standards and for the sera separately in the same way as in Figure 12. The regression coefficients of $\mathrm{y}$ upon $\mathrm{x}$ were 125.2 and 118.2, respectively. In addition, the data of the insulin standards, of suppressible ILA, and of nonsuppressible ILA were correlated separately. The three regression coefficients were $124.0 \pm 4.9 \mathrm{SD}, 114 \pm 11.2$, and 103 \pm 16.7 , respectively (Figure 12 ).

\section{DISCUSSION}

A procedure for the determination of serum ILA with pooled epididymal adipose tissue of 12 rats for each assay, based on the simultaneous measurement of glucose uptake and of net gas exchange, is described. The critical point in this procedure is the preparation of the tissue pool, when the collaboration of three persons is required for 30 minutes. The precision appears to be the result of the pool design and of the large number of animals used per assay. The other group of investigators (10) who reported an index of precision below 0.20 also incubated pooled tissue rather than single tissue pieces. Evidently, the advantages of such a pool design are turned into disadvantages when the tissue pieces from each rat are not dissected to as nearly an equal size as possible.

Besides glucose uptake, net gas exchange was chosen as a metabolic index of ILA. The net gas exchange of adipose tissue reflects the respiratory quotient of this tissue and parallels fatty acid synthesis from glucose (30) (Figure 4). Serum equilibrated with $95 \% \mathrm{O}_{2}$ and $5 \% \mathrm{CO}_{2}$ was shown to release less $\mathrm{CO}_{2}$ into the gas phase upon addition of lactic acid (Figure 1) and to retain more of the $\mathrm{CO}_{2}$ produced during incubation (Figure 5) than Krebs-Ringer bicarbonate buffer. Similar buffering capacity of the two incubation media used in the insulin assay was achieved by diluting the sera $1: 5$ and by adding $1.5 \mathrm{~g}$ albumin per 100 $\mathrm{ml}$ to the buffer containing the insulin standards. The influence of physiologic concentrations of two major metabolites in human serum, i.e., lactic acid and FFA, on net gas exchange and glucose uptake was examined and found to be negligible.

The simultaneous measurement of glucose uptake and net gas exchange was suited to determine whether the effects of serum on adipose tissue are truly "insulin-like," or whether hormones with lipolytic activity might interact, since these hormones have been shown to stimulate glucose uptake out of proportion to fatty acid synthesis and net gas exchange $(20-23,35)$. The average ILA of a heterogeneous group of 104 sera was $200 \mu \mathrm{U}$ per $\mathrm{ml}$ by glucose uptake and $195 \mu \mathrm{U}$ per $\mathrm{ml}$ by net gas exchange (Table III). Furthermore, net gas exchange and glucose uptake were correlated separately for the insulin standards and for the sera, and very similar regression coefficients of 125.17 and 118.21, respectively, were obtained. These observations signify that the effects of diluted serum on these metabolic indexes of adipose tissue are similar to those of crystalline insulin and that there are no hormonal or other factors that would raise glucose uptake out of proportion to net gas exchange. Similar conclusions were reached by Leonards, Landau, and Bartsch (36), who reported good agreement between the effects of insulin and serum ILA on a variety of indexes of adipose tissue metabolism.

In contrast to Ball and Merrill (11), who also used net gas exchange of adipose tissue to determine serum ILA, we found no increase of ILA upon serum dilution, provided that a correction was applied for the increased buffering capacity of undiluted serum. Ball and Merrill did not take into consideration the problem of $\mathrm{CO}_{2}$ retention in the medium, which might explain the discrepancies between their results and ours. Sheps and co-workers (4) and Lyngsøe (16) found an increase of serum ILA upon dilution by using the oxidation of glucose-1- $\mathrm{C}^{14}$ to $\mathrm{C}^{14} \mathrm{O}_{2}$ as a metabolic index. According to Lyngs $\varnothing$ e, serum ILA in normal fasting subjects amounts to $71 \mu \mathrm{U}$ per $\mathrm{ml}$ undiluted serum and to $174 \mu \mathrm{U}$ per $\mathrm{ml}$ when determined in serum diluted 1:5. Adipose tissue might conceivably oxidize unlabeled substrates such as lactic acid, which might lead to diminished oxidation of glucose in undiluted serum. Therefore, it cannot yet be decided whether the slight dilution effect on serum ILA observed by these investigators is of any physiologic significance or not. In any event, the increase of serum ILA upon dilution is of a different order of magnitude with the diaphragm $(18,19)$, and it has been shown that an insulin antagonist associated with plasma albumin is likely to be responsible for this effect (37). It would appear from the data in 
this report as well as from other studies (38) that, in contrast to the diaphragm, albumin does not antagonize the action of endogenous and exogenous insulin on adipose tissue.

Anti-insulin guinea-pig serum abolishes insulin action on adipose tissue entirely, and this property of anti-insulin serum was exploited for a combined immunological and biological insulin assay. The insulin antibody possessing the electrophoretic mobility of a $\gamma$-globulin reacts also with human insulin and inhibits the effects of crystalline human insulin on adipose tissue completely. Only $7 \%$ of total serum ILA of normal fasting subjects, i.e., $13 \mu \mathrm{U}$ per $\mathrm{ml}$, was suppressible. Samaan, Stillman, and Fraser (39), using a similar technic, reported an average suppressible ILA of $53 \mu \mathrm{U}$ per $\mathrm{ml}$ in fasting normal subjects.

The results shown in Table VI demonstrate that maximal suppression of ILA was reached with a dose of anti-insulin serum well below the one used in these experiments. Glucose uptake and net gas exchange were not further depressed by an increase in the amount of anti-insulin serum from 0.025 to $0.200 \mathrm{ml}$ per $\mathrm{ml}$ serum. This finding excludes the possibility that the differentiation of serum ILA into two fractions with different immunological behavior might result merely from the competition of the insulin antibody for insulin binding with a carrier protein in serum. If this were the case, one would expect more ILA to become suppressible as the concentration of antibody increased.

According to Antoniades (40) and Shaw and Shuey (41), "free" insulin is released from a "bound" form in serum by incubation with adipose tissue homogenates. If such a process also took place in the presence of intact adipose tissue, the insulin "freed" during incubation might become subject to antibody suppression, and a progressive fall of the concentration of nonsuppressible ILA would be expected. Figure 6 shows that the net gas exchange of adipose tissue proceeded linearly whether adipose tissue was incubated in the absence or presence of anti-insulin serum. Contrary to this, the effects of crystalline insulin were entirely neutralized within 20 minutes after addition of anti-insulin serum, even after prolonged preincubation with insulin (Figure 7 ). Intravenous injection of regular insulin led to a sharp rise of suppressible ILA, whereas nonsup- pressible ILA remained unchanged, suggesting that exogenous insulin was not converted to nonsuppressible ILA (Table VII). After oral and prolonged iv glucose administration to normal subjects, there was a rise of suppressible ILA that correlated with the blood sugar level. No consistent effect on nonsuppressible ILA was observed (Figure 8).

Suppressible ILA was elevated in five out of six patients with $\beta$-islet-cell adenoma and averaged $252 \mu \mathrm{U}$ per ml, whereas nonsuppressible ILA was normal (Figures 9 and 10). Two of these patients, one of whom had no suppressible ILA on two occasions, were submitted to an oral tolerance test with L-leucine. In both, severe hypoglycemia developed rapidly, and suppressible ILA rose to abnormally high levels of 209 and $595 \mu \mathrm{U}$ per $\mathrm{ml}$, respectively. Since only suppressible ILA was elevated in patients with $\beta$-islet-cell adenoma, it became at once apparent why the determination of suppressible ILA was a much more meaningful diagnostic tool than the measurement of total ILA.

Untreated patients with diabetes mellitus of recent onset appeared to have values of suppressible ILA that were higher than those of fasting normal subjects, but appreciably lower than those after glucose administration and at comparable blood sugar levels in normal subjects (Figure 11 and Table VIII). There appeared to be no correlation between blood sugar and suppressible ILA among these patients with diabetes mellitus.

All these findings suggest that suppressible ILA acts on the tissues in vivo and that it regulates the blood sugar. Our values of suppressible ILA in normal subjects before and after glucose administration correspond closely to those found by Yalow and Berson (15) and Samols and Ryder (42) by immunoassay, and suppressible ILA might well be identical with their serum insulin.

The mean levels of nonsuppressible ILA were remarkably uniform within the various groups of patients studied. In particular, patients in diabetic coma exhibited normal levels of nonsuppressible ILA. If this substance were active on adipose tissue in vivo to the same extent as in vitro, it might be expected to prevent the development of this severe derangement of carbohydrate and fat metabolism. One may speculate that nonsuppressible ILA mav not be present in 
the interstitial fluid and that it may not achieve contact with the adipose tissue cell in vivo.

It has not yet been established whether nonsuppressible ILA is effective on muscle in vitro or not. Stimulation of the glucose uptake of rat diaphragm produced by beef serum may be entirely abolished by the addition of anti-insulin serum (28), whereas the effects of beef serum extracts were inhibited to an extent of $70 \%$ (43); purified insulin antibodies have not, however, been used to rule out a possible interaction of insulin inhibitors other than antibodies. If total serum ILA were inhibited by insulin antibodies in the diaphragm assay, the question would remain unanswered why the results of serum ILA obtained with the diaphragm were often found to lie within the same high range $(18,19)$ as those obtained with adipose tissue. It has been conclusively demonstrated that the influence of nonsuppressible ILA on net gas exchange and glucose uptake of adipose tissue cannot be distinguished from that of crystalline insulin (Figure 12). Other preliminary results from this laboratory suggest that nonsuppressible ILA may, indeed, be related to the insulin molecule (44). Nonsuppressible ILA has been reproducibly extracted from serum with acid ethanol. The effects of partially purified nonsuppressible ILA on adipose tissue in vitro were identical with those of crystalline insulin (44). Furthermore, nonsuppressible ILA decreased considerably in rats rendered diabetic with alloxan, and the severity of the diabetic state correlated with the reduction of nonsuppressible ILA (45). Other investigators found a less marked fall of total serum ILA after pancreatectomy in dogs and cats (46).

Whether nonsuppressible ILA might be released by the $\beta$-islet-cells as such, or whether it might be a product of transformation of the insulin molecule by some other organ remains obscure. Samaan, Demptster, Fraser, and Stillman (47) found an increase of nonsuppressible ILA after passage of crystalline insulin through the liver in vivo, and they suggested that the liver might convert pancreatic insulin to the nonsuppressible form. Our results do not support this hypothesis. Nonsuppressible ILA did not rise after insulin injection and after glucose administration to normal subjects, although in both instances there was a considerable increase of sup- pressible ILA. Furthermore, nonsuppressible ILA was not restored to normal in alloxandiabetic rats after prolonged insulin substitution (45). Lastly, crystalline rat insulin was rapidly inactivated by rat liver perfused in vitro in the presence of albumin, but it was not converted to nonsuppressible ILA (48).

Antoniades, Gundersen, and Pyle (49) reported a consistent and marked decrease of "bound" insulin after glucose administration to normal subjects. Nonsuppressible ILA remained unchanged under these conditions, and these two substances would appear to be different entities.

\section{SUM M ARY}

1) An adipose tissue assay for serum insulinlike activity (ILA) is described that makes use of glucose uptake and net gas exchange as metabolic indexes. Owing to a tissue pool design of 12 rats per assay, satisfactory precision was obtained. 2) Upon serum dilution, there was a proportional decrease of serum ILA, provided that the values of net gas exchange were corrected for increased $\mathrm{CO}_{2}$ retention in undiluted serum. 3) Results of serum ILA from both metabolic indexes correlated well. Serum diluted 1:5 appeared to influence these two metabolic indexes in a similar manner as crystalline insulin. 4) Only $7 \%$ of total serum ILA of normal fasting subjects was suppressed by anti-insulin serum. Upon iv injection of regular insulin to normal subjects, suppressible ILA rose, whereas nonsuppressible ILA did not change. Oral and iv glucose administration led to a rise of suppressible ILA that was related in magnitude to the blood sugar level. 5) In most serum samples of six patients with active $\beta$-isletcell adenoma, suppressible ILA was elevated and nonsuppressible ILA was normal. 6) In patients with untreated diabetes mellitus of recent onset, suppressible ILA was higher than in fasting normal subjects, but much lower than in normal subjects at comparable blood sugar levels. Suppressible ILA was not detected in patients in diabetic coma who had normal levels of nonsuppressible ILA. 7) Preliminary evidence suggests that nonsuppressible ILA affects adipose tissue metabolism in a way similar to crystalline insulin, that it is less effective in vivo than in vitro, or ineffective, and that it may be closely related to the insulin molecule. 


\section{ACKNOWLEDGMENT}

We wish to thank Misses P. Unseld, S. Diem, R. Krüger, and U. Westermayer for their skilled technical assistance, Drs. A. E. Renold and A. I. Winegrad for valuable criticism, and Mrs. M. Fanconi for her help with the preparation of the manuscript.

\section{ADDENDUM}

Since submission of this manuscript additional information on the nature of nonsuppressible ILA has accumulated. Nonsuppressible ILA was repeatedly extracted from serum, and it was partially purified to an activity of $1 \mathrm{mU}$ per mg protein. Upon chromatography on Sephadex G-200, nonsuppressible ILA was eluted at $60 \%$ of the volume of the column, indicating a molecular weight of approximately 70,000 . The activity of this material was entirely abolished by a 3 -hour incubation in $0.2 \mathrm{~N}$ $\mathrm{KOH}$ at $37^{\circ} \mathrm{C}$. Cystein alone did not inactivate nonsuppressible ILA. Complete inactivation was obtained by preincubation with cystein in combination with $8 \mathrm{M}$ urea. Partially purified nonsuppressible ILA stimulated the incorporation of uniformly labeled glucose- $\mathrm{C}^{14}$ into glycogen of the mouse diaphragm to approximately the same degree as crystalline insulin. Whereas the effects of crystalline insulin on the mouse diaphragm were suppressed in the presence of anti-insulin $\gamma$-globulin, nonsuppressible ILA remained active. These findings support our hypothesis that nonsuppressible ILA acts on tissues in vitro in a very similar way to insulin.

\section{REFERENCES}

1. Jeanrenaud, B. Dynamic aspects of adipose tissue metabolism: a review. Metabolism 1961, 10, 535.

2. Martin, D. B., A. E. Renold, and Y. M. Dagenais. An assay for insulin-like activity using rat adipose tissue. Lancet 1958, 2, 76.

3. Renold, A. E., D. B. Martin, Y. M. Dagenais, J. Steinke, R. J. Nickerson, and M. C. Sheps. Measurement of small quantities of insulin-like activity using rat adipose tissue. I. A proposed procedure. J. clin. Invest. 1960, 39, 1487.

4. Sheps, M. C., R. J. Nickerson, Y. M. Dagenais, J. Steinke, D. B. Martin, and A. E. Renold. Measurement of small quantities of insulin-like activity using rat adipose tissue. II. Evaluation of performance. J. clin. Invest. 1960, 39, 1499.

5. Ditschuneit, H., C-S. Ahn, M. Pfeiffer, and E. F. Pfeiffer. Ueber die Bestimmung von Insulin im Blute am epididymalen Fettanhang der Ratte mit Hilfe markierter Glucose. Klin. Wschr. 1959, 37, 1234.

6. Weinges, K. F., and H. Wörner. Über den Einfluss von Insulin und Glukagon auf den Glucosestoffwechsel des epididymalen Fettanhangs der Ratte in vitro. I. Der Einfluss von Insulin und die sich daraus ergebende Möglichkeit der Bestimmung einer insulinähnlichen Aktivität im menschlichen Blut. Klin. Wschr. 1961, 39, 238.
7. Lyngsøe, J. Determination of the insulin-like activity in serum using rat epididymal adipose tissue. Scand. J. clin. Lab. Invest. 1961, 13, 628.

8. Humbel, R. E. Messung der Serum-Insulin-Aktivität mit epididymalem Rattenfettgewebe in vitro. Experientia (Basel) 1959, 15, 256.

9. Beigelman, P. M. Insulin-like activity of normal and diabetic human serum. Diabetes 1959, 8, 29.

10. Steelman, S. L., R. Oslapas, and R. D. Busch. An improved in vitro method for determination of serum "insulin-like" activity. Proc. Soc. exp. Biol. (N. Y.) 1960, 105, 595.

11. Ball, E. G., and M. A. Merrill. A manometric assay of insulin and some results of the application of the method to sera and islet-containing tissues. Endocrinology 1961, 69, 596.

12. Vallance-Owen, J., and B. Hurlock. Estimation of plasma-insulin by the rat diaphragm method. Lancet 1954, 1, 68.

13. Wright, P. H. Plasma-insulin estimation by the rat-diaphragm method. Lancet 1957, 2, 621.

14. Seltzer, H. S., and W. L. Smith. Plasma insulin activity after glucose. An index of insulogenic reserve in normal and diabetic man. Diabetes 1959, 8, 417.

15. Yalow, R. S., and S. A. Berson. Immunoassay of endogenous plasma insulin in man. J. clin. Invest. $1960,39,1157$.

16. Lyngsøe, J. The insulin-like activity in serum determined by the rat epididymal fat method. I. Normal values in undiluted and diluted serum, and the effect of ingestion of glucose. Acta med. scand. 1962, 171, 365.

17. Pfeiffer, E. F., M. Pfeiffer, H. Ditschuneit, and C-S. Ahn. Ueber die Bestimmung von Insulin im Blute am epididymalen Fettanhang der Ratte mit Hilfe markierter Glucose. Klin. Wschr. 1959, 37, 1239.

18. Randle, P. J. Insulin in blood. Ciba Found. Colloq. Endocr. 1957, 11, 115.

19. Willebrands, A. F., H. Van der Geld, and J. Groen. Determination of serum insulin using the isolated rat diaphragm. The effect of serum dilution. Diabetes 1958, 7, 119.

20. Froesch, E. R., P. Bally, U. Guhl, E. B. Ramseier, and A. Labhart. Die Wirkung des Glukagons auf das Fettgewebe. Schweiz. med. Wschr. 1960, 90, 1329.

21. Winegrad, A. I., W. N. Shaw, F. D. W. Lukens, W. C. Stadie, and A. E. Renold. Effects of growth hormone in vitro on the metabolism of glucose in rat adipose tissue. J. biol. Chem. 1959, 234, 1922.

22. Leboeuf, B., and G. F. Cahill, Jr. Studies on rat adipose tissue in vitro. VIII. Effect of preparations of pituitary adrenocorticotropic and growth hormones on glucose metabolism. J. biol. Chem. 1961, 236, 41.

23. Cahill, G. F., Jr., B. Leboeuf, and R. B. Flinn. Studies on rat adipose tissue in vitro. VI. Effect 
of epinephrine on glucose metabolism. J. biol. Chem. 1960, 235, 1246.

24. Renold, A. E., J. Ashmore, and B. A. Hastings. Regulation of carbohydrate metabolism in isolated tissues in Vitamins and Hormones, R. S. Harris, G. F. Marrian, and K. V. Thimann, Eds. New York, Academic Press, 1956, p. 139.

25. Kipnis, D. M., E. Helmreich, and C. F. Cori. Studies on tissue permeability. IV. The distribution of glucose between plasma and muscle. J. biol. Chem. 1959, 234, 165.

26. Groen, J., A. F. Willebrands, H. G. Van der Geld, and R. E. Bolinger. Determination of serum insulin in patients with islet cell tumours of the pancreas. Ciba Found. Colloq. Endocr. 1958 $12,255$.

27. Berson, S. A., and R. S. Yalow. Insulin inhibitors and insulin resistance. N. Y. St. J. Med. 1960, 60, 3658.

28. Taylor, K. W., and P. J. Randle. The effect of insulin antiserum on the insulin activity of serum and protein fractions of serum. J. Endocr. 1959, 19, 221.

29. Ramseier, E. B., E. R. Froesch, P. Bally, and A. Labhart. Serum-Insulinbestimmung am Fettgewebe in vitro: Beeinflussung durch andere Hormone, "freie" und "gebundene" Insulinaktivität in 4th Congr. int. Diabetes Fed., Geneva, Médecine et Hygiène, 1962, p. 643.

30. Froesch, E. R., and J. Ginsberg. Fructose metabolism of adipose tissue. I. Comparison of fructose and glucose metabolism in epididymal adipose tissue of normal rats. J. biol. Chem. 1962, 237, 3317.

31. Bürgi, H., E. B. Ramseier, E. R. Froesch, P. Bally, and A. Labhart. "Freies" und "gebundenes" Insulin im Serum von Patienten mit B-InselzellAdenom. Helv. med. Acta 1962, 29, 527.

32. Umbreit, W. W., R. H. Burris, and J. F. Stauffer. Manometric Technics and Related Methods for the Study of Tissue Metabolism. Minneapolis, Burgess, 1957, p. 58.

33. Gordon, R. S., Jr. Unesterified fatty acid in human blood plasma. II. The transport function of unesterified fatty acid. J. clin. Invest. 1957, 36, 810.

34. Moloney, P. J., and M. Coval. Antigenicity of insulin: diabetes induced by specific antibodies. Biochem. J. 1955, 59, 179.

35. Jungas, R. L., and E. G. Ball. Studies on the metabolism of adipose tissue. V. The effect of a growth hormone preparation and insulin on the oxygen consumption, glucose uptake, and lactic acid production. J. biol. Chem. 1960, 235, 1894.
36. Leonards, J. R., B. R. Landau, and G. Bartsch. Assay of insulin and insulin-like activity with rat epididymal fat pad. J. Lab. clin. Med. 1962, 60, 552.

37. Vallance-Owen, J., and M. D. Lilley. An insulin antagonist associated with plasma-albumin. Lancet 1961, 1, 804.

38. Lowy, C., G. Blanshard, and D. Phear. Antagonism of insulin by albumin. Lancet 1961, 1, 802.

39. Samaan, N. A., D. Stillman, and R. Fraser. Abnormalities of serum insulin-like activity in liverdisease. Lancet 1962, 2, 1287.

40. Antoniades, H. N. Studies on the state of insulin in blood: the state and transport of insulin in blood. Endocrinology 1961, 68, 7.

41. Shaw, W. N., and E. W. Shuey. The presence of two forms of insulin in normal human serum. Biochemistry 1963, 2, 286.

42. Samols, E., and J. A. Ryder. Studies on tissue uptake of insulin in man using a differential immunoassay for endogenous and exogenous insulin. J. clin. Invest. 1961, 40, 2092.

43. Cunningham, N. F. The insulin activity of bovine and ovine blood plasma. II. The insulin-like action of extracts of bovine and ovine blood plasma. J. Endocr. 1962, 25, 43.

44. Froesch, E. R., H. Bürgi, W. Müller, and A. Labhart. Unpublished observations.

45. Froesch, E. R. Insulin im Blut: durch Insulin-Antikörper hemmbare und nicht hemmbare Insulinaktivität und ihre physiologische Bedeutung in Fortschritte der Diabetesforschung, K. Oberdisse and K. Jahnke, Eds. Stuttgart, Georg Thieme, 1963, p. 30 .

46. Stcinke, J., A. Sirek, V. Lauris, F. D. W. Lukens, and A. E. Renold. Measurement of small quantities of insulin-like activity with rat adipose tissue. III. Persistence of serum insulin-like activity after pancreatectomy. J. clin. Invest. 1962, 41, 1699.

47. Samaan, N. A., W. J. Demptster, R. Fraser, and D. Stillman. Changes in levels of "atypical" circulating insulin after infusing "typical" insulin through the liver. J. Endocr. 1963, 26, 1.

48. Bürgi, H., K. Kopetz, K. Schwarz, and E. R. Froesch. The fate of rat insulin in rat liver perfusion studied by adipose tissue assay. Lancet 1963, 2, 314.

49. Antoniades, H. N., K. Gundersen, and H. M. Pyle. Studies on the state of insulin in blood: the role of glucose in the in vivo dissociation of insulin complexes. Endocrinology 1961, 69, 163. 